\title{
The Late PPNB "World" Systems in Northern Mesopotamia and South Levant: agglomeration, control of long distance exchange and the transition of early religious centers to central villages
}

\author{
El Sistema "Mundial" del PPNB Final en el Norte de \\ Mesopotamia y el Sur del Levante: Aglomeraciones, control \\ del intercambio a larga distancia y transición de los primeros \\ centros religiosos a poblados centrales
}

Jesús Gil Fuensanta ${ }^{1}$

Alfredo Mederos Martín²

\begin{abstract}
During the Aceramic Neolithic (PPN) period of the Near East, many economic and societal changes took place. During the PPNA is when we recognize a process of agglomeration of hundreds people in big sites such as Jericho. The archaeological record proves more than likely contacts between the contemporary societies of the Levant and some Eastern and Central Anatolian sites. The extent of those far contacts is hard to estimate, but we assume that such contacts and the trade network, which we can study mainly through the obsidian trade, using terrestrial and maritime routes, with the interaction of big villages though a few intermediary steps, already full operating at that time, must have helped to transform the local hierarchies, economic interdependences and rituals, and for instance it could accelerated the end of Göbekli Tepe around mid PPNB. And therefore during the Late PPNB consolidated the central villages, key nodes in the trade networks, and these, in different ecological regions, reached between 10 and 15 ha, v. gr. in Basta, Beisamoun or 'Ain Ghazal. And in such a way, those built interdependent Ancient "World" Systems.
\end{abstract}

Keywords: Aceramic Neolithic, Göbekli Tepe, Çayönü, Aşikli, Jericho, ritual places, sedentary villages, obsidian, trade, surplus, Ancient World Systems.

\begin{abstract}
Resumen
Durante el Neolítico Precerámico (PPN) del Próximo Oriente, tuvieron lugar muchos cambios económicos y sociales en el PPNA, cuando identificamos un proceso de aglomeración de centenares de personas en grandes asentamientos como Jericó. El registro arqueológico prueba notables contactos entre las sociedades contemporáneas en el Levante y algunos asentamientos de Anatolia central y oriental. La entidad de estos contactos es difícil de estimar, pero asumimos que tales contactos y las redes de intercambio, las cuales podemos estudiar principalmente a través del comercio de obsidiana, usando rutas terrestres y marítimas, con la interacción de grandes asentamientos a través de pocos intermediarios, ya estaban plenamente operativas en ese periodo, y debieron haber ayudado a transformar las jerarquías locales, creando interdependencias económicas y rituales, aceleradas después del final de Göbleki Tepe en el PPNB Medio. Entonces se consolidaron los grandes asentamientos, nodos en las redes de intercambio, que alcanzaron entre 10 y 15 ha en diferentes regiones ecológicas como Basta, Beisamoun o 'Ain Ghazal durante el PPNB Final, y construyendo de tal modo Antiguos Sistemas "Mundiales" interdependientes.
\end{abstract}

Palabras clave: Neolítico Precerámico, Göbekli Tepe, Çayönü, Aşikli, Jerico, centros rituales, poblados sedentarios, obsidiana, comercio, excedente, Sistemas Mundiales Antiguos

LA SEI-ICFS (Instituto de Ciencias Forenses), Universidad Autónoma de Madrid. eurasia.icfs@uam.es

Departamento de Prehistoria y Arqueología, Universidad Autónoma de Madrid. alfredo.mederos@uam.es 


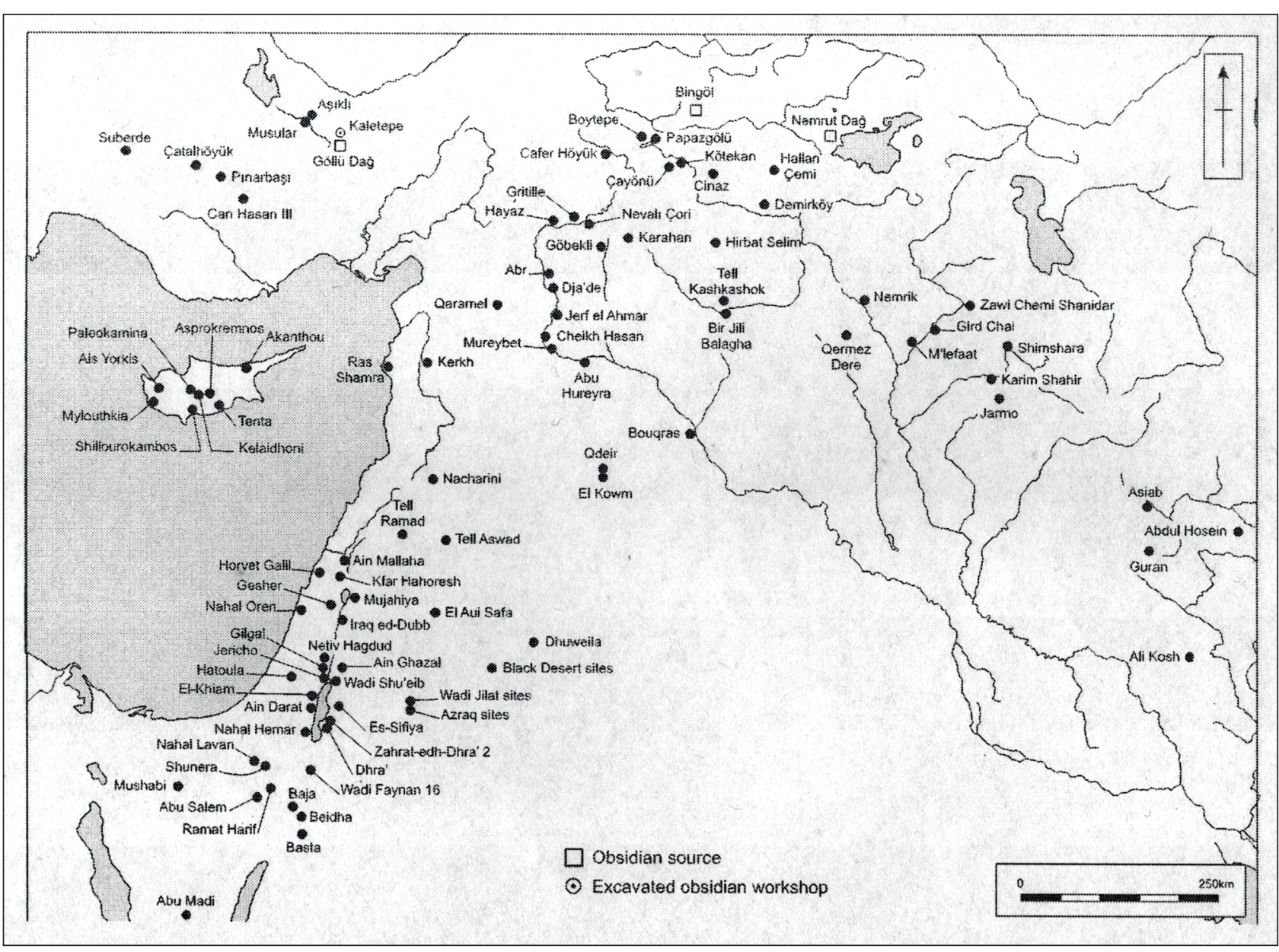

Figure 1. Main settlements during the PPNA and PPNB, and its relationship with obsidian sources (Asouti, 2006: 89 fig. 1).

\section{INTRODUCTION}

A turning event either for the History and the Near Eastern civilizations took place during the early agrarian societies and the invention of agriculture in the Pre-Pottery Neolithic (PPN). This period of the South Levant (nowadays Israel, Jordan and Palestine) has been compared to the PPN cultural development occurred in the closer regions during the same epoch, $c a$. X to VIII Millennia BC. On the other hand, the PPNB phase of the Levant shares common characters with the cultures of Middle Euphrates and Southeastern Anatolia (Verhoeven, 2002). Since the early 1980s, most of the already known concepts about the Aceramic Neolithic (specially the phase A) have changed slightly. During the last twenty years, more light has been shed upon the PPNA phase (9800-8800 BC) in special in the Turkish Euphrates and Tigris areas and in Southern Levant sites, previously less known even than the preceding Epi-Paleolithic/Natufian phases (Belfer-Cohen, 1991; Bar-Yosef, 2002) (fig. 1).

However, the existence of a PPN phase in Western Turkey has been the focus of a long controversy among scholars. Several archaeologists guessed that the industries of Ceramic and Aceramic Neolithic are different (Özdogan, 1999: 211). Suberde remains a key site for the study of the period in the region. It is supposed to be the outcome of a Westward movement at the very end of the Aceramic period, after a sparse and random migration following the mountain ranges (Özdogan, 1999: 212; Brami, 2014: 210214) (fig. 2a-2b).

The environmental question is still on debate, and specially regarding the global warming, $c a .9200 \mathrm{BC}$, after the Younger Dryas (Dryas III), an arid period during 1300 years (Alley et al., 2000; Maher, Banning and Chazan, 2011: 7-8, 17), a date fitting in most of the PPNA sites discovered around the Middle Euphrates, including the earliest erection of the monumental buildings at Göbekli Tepe, Southeastern Turkey, when the colder and dry weather of the Epipaleolithic gave way to new, milder conditions, consisting of a wetter climate because the increase in precipitations, also during the summer months (Bar-Yosef, 2001a and 2002). The later Epipaleolithic populations of the area experienced during the period an altered environment, then with more fertile conditions, plus a lot of vegetation and new expansion of forest, including plenty of animal species living there, in a diversified number of habitats. Thus it became a more suitable environment for groups devoted to hunting and foraging and for the limited settlement of a few (but not all of them) into a selected, and still smaller group of sites, scarce in comparison to the whole nomadic or half-nomadic populations of the area, usually confined to a mobility basis. We are aware that many sites could have vanished because the erosion or sedimentation processes. The earliest moments of the 


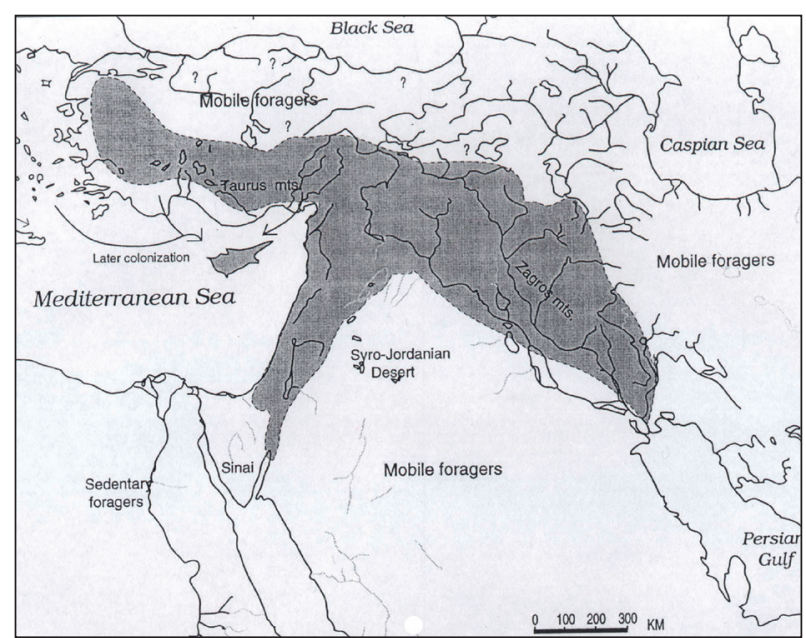

Figure 2a. Proposal of a PPNB west expansion in Anatolia (Bar-Yosef, 2001: 144 fig. 5).

PPN culture, in spite of these benevolent environmental conditions, displays a society with strong ties to the former regional Epipaleolithic periods, in addition to remarkable exceptions such as the new use of open-air villages (Cauvin, 1997; Bar-Yosef and Belfer-Cohen, 1989: 448; Starkovich and Stiner, 2009: 43).

\section{The big ritual center of Gobleki Tepe and the FALL OF THE HUNTER ClANS OF THE PPNA}

In accordance with the PPNA mentality, centers, such as Göbekli Tepe, 9600-8800 BC, with 9 ha (Schmidt, 2006 and 2007: 268, 271), founded their control mostly through religion, rituals and exchange of far distant commodities (obsidian, peculiar flint types). Some researchers have suggested that only a limited amount of people, such as the leaders or members of the elite gathered in the central places of each place (Hole, 2000). Another interpretation, it is focused on the celebration of feasting and dancing with drinking of beer made from fermented wild crops (Schmidt, 2007: 266; Dietrich et al., 2012: 690-692; Hauptmann, 1999: fig. 16), maybe also including grape wine, detected in two stone bowls from Körtik Tepe (McGovern, 2009: 81) (fig. 3).

Overwhelming public works were concentrated along the PPNA. The earliest apparition of monumental buildings ocurred during the earlier PPNA settlement of Göbekli Tepe, and so stood for centuries. The labor of the movement of a few tons, required at least dozens of peoples, if not a couple of hundreds, at most during a season of a year (Schmidt, 2015) (fig. 4a-4b).

Along the PPNA, Göbekli Tepe's Enclosure A, 8900 BC (Schmidt, 2015: 188), with elliptical plan and the representations of the serpents abound on the pillars, was altered after its construction. The Enclosure B was more recent than Enclosure A, and there prevails the iconography of the fox (Schmidt, 2015: 185). But we interpret the $\mathrm{C}$ Building as the oldest of this circular complex. And it

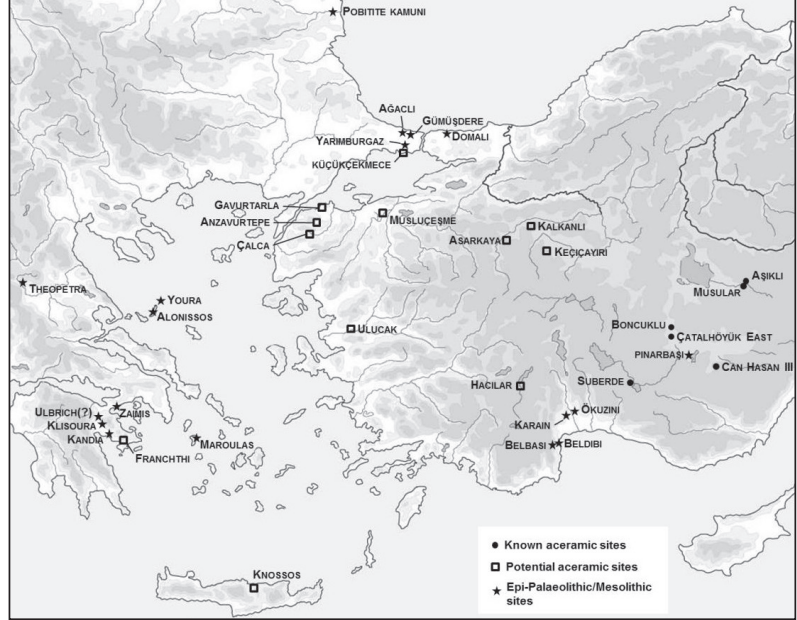

Figure 2b. Potencial aceramic sites in West Anatolia (Brami, 2014: 212 fig. 28).

stands out above the others, in which there was an access dromos (Schmidt, 2015: 221). Its central pillars were destroyed, perhaps shortly after the ritual filling of the after the buildings' abandonment during the final stages of the PPNA. This Building, on the other hand, is remarkable for being the enclosure where the representations of wild boar are concentrated. We remind that the boar is an omnipresent element in Çayönü through the whole occupation of that site. Last, the better preserved Enclosure

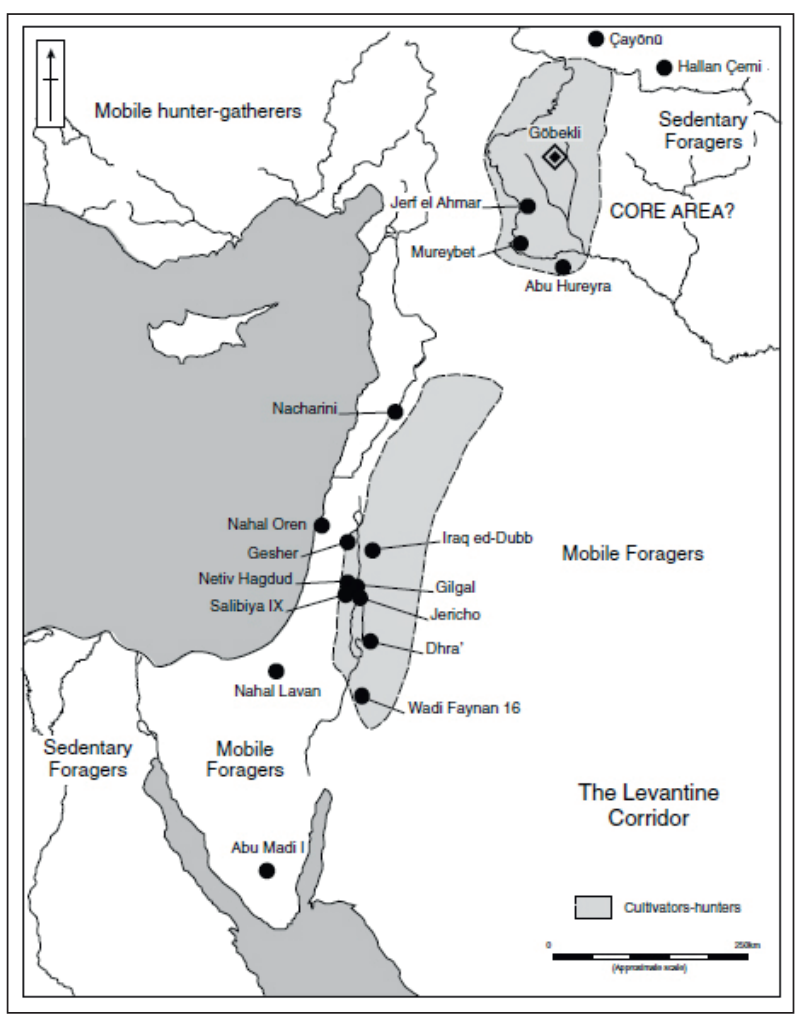

Figure 3. PPNA settlements (Asouti, 2006: 91 fig. 3, after Bar-Yosef, 2001: 19 fig. 4). 


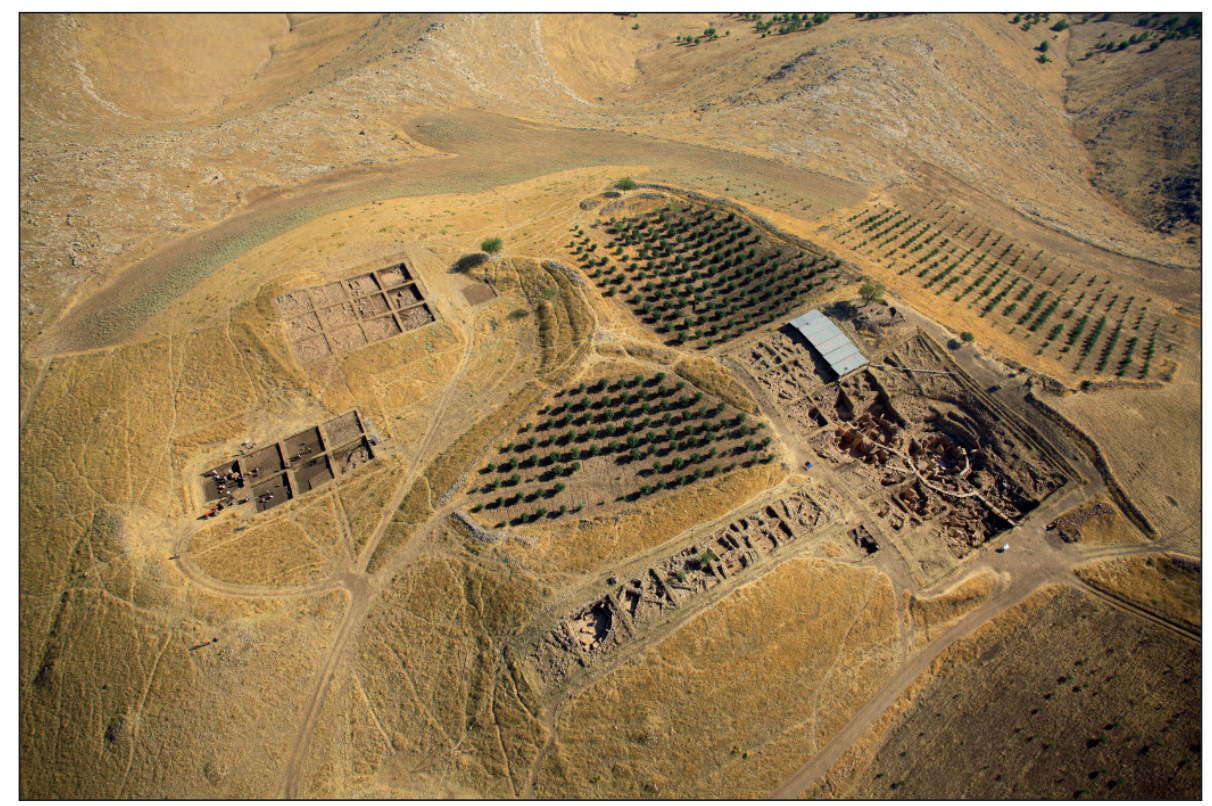

Figure 4a. Aerial view, Gobleki Tepe. DAI.

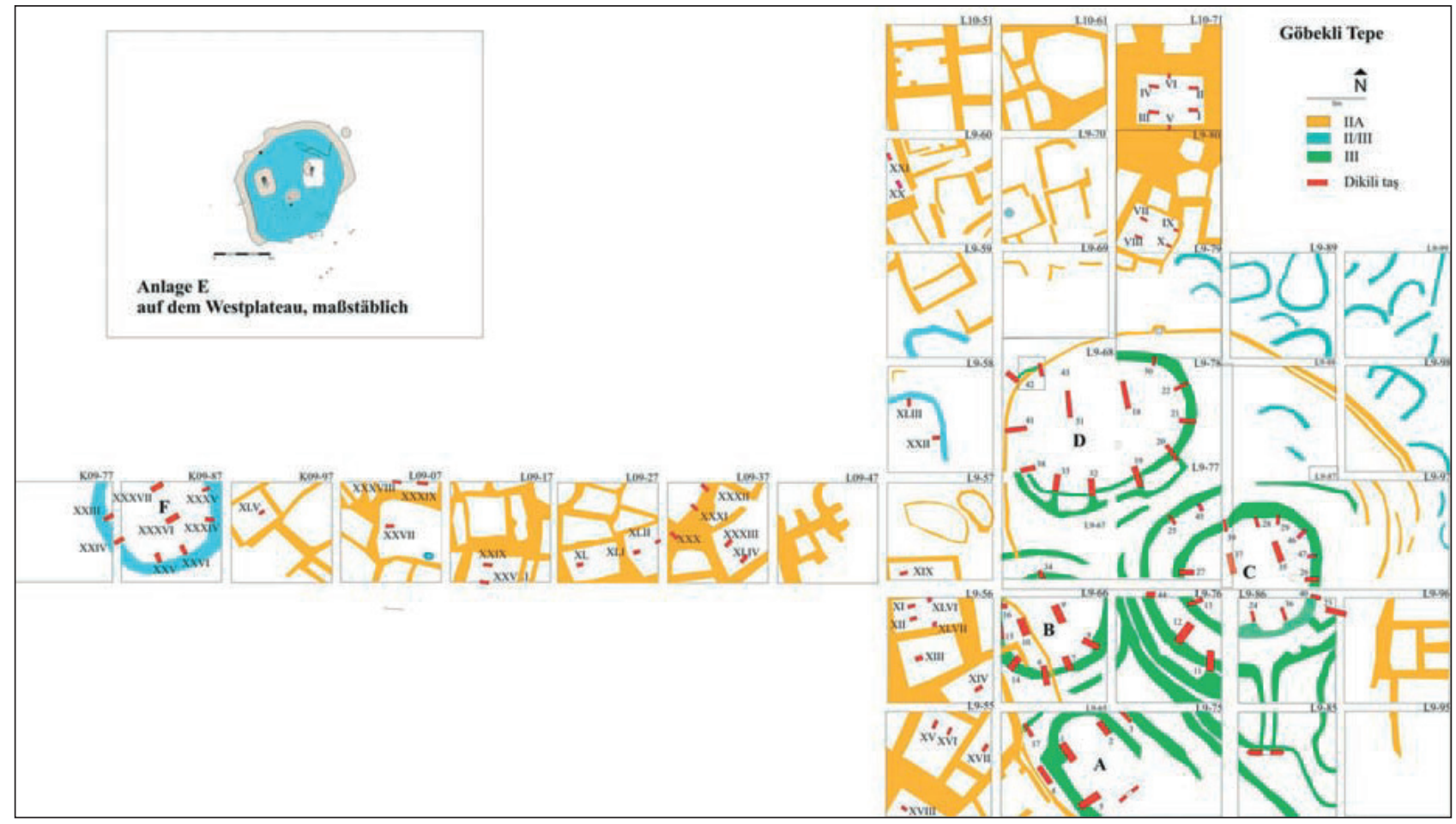

Figure 4b. Gobleki Tepe, site plan (Schmidt, 2010: 240 fig. 2).

D had two central pillars, which could be masculine, an element of predominance in the ritual world of Göbekli Tepe (Peeters and Schmidt, 2004: 214; Hauptmann and Schmidt, 2007; Notroff, Dietrich and Schmidt, 2016: 68; contra, Banning, 2011). At the Enclosure D, despite its variety of iconography, had the predominance of birds (Peeters and Schmidt, 2004: 185 table 2, 211). The pig "imaginery", it leads to think of the Tigris area, the Zagros or Taurus piedmont areas, as a compact regional culture during the PPNA. Perhaps the limit of that regional area would be perceived on Göbekli Tepe, a possible border or limitation point for the cultural clans of the mentioned Tigris-Euphrates areas during the PPNA. The presence of pigs in other places, such Hallan Çemi or Çayönü had to obey not only due to their suitable need in a colder and wetter climate, compared to nowadays conditions, during the winters of the period, but also to some kind of ritual belief of the clan or tribe present in the place (fig. 5a-5b). 


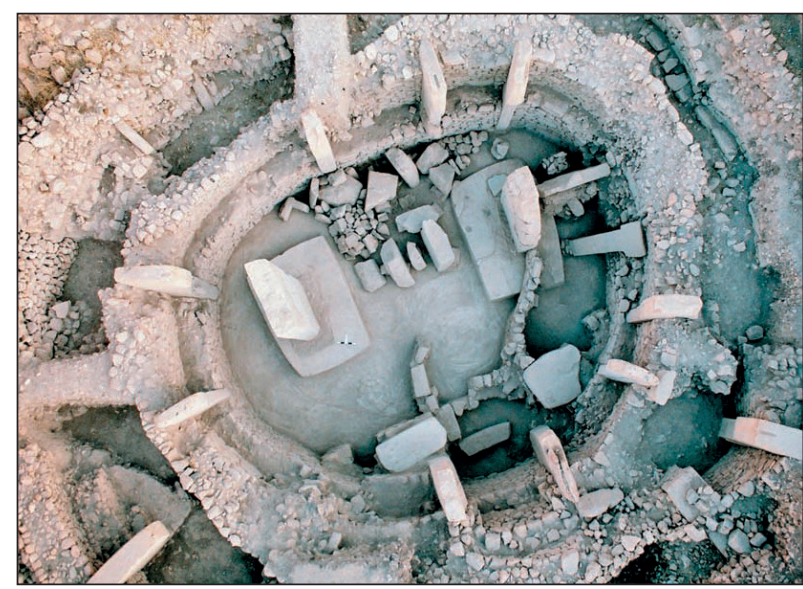

Figure 5a. Gobleki Tepe, Enclosure C, aerial view (Schmidt, 2010: 251 fig. 22).

The omnipresent symbology of two twin pillars on pedestals, in the center of each circular building suggests different clan totems of social groups: fox, wild boar, crow, lion, serpent, and so on (Peeters and Schmidt, 2004: 210; Rubio de Miguel, 2004: 155; Schmidt, 2007: 278; Notroff, Dietrich and Schmidt, 2016: 73), a kind of protective animals of the clan or tribe that constructed the building in question. Banks in the interior and other features of the Göbekli enclosures lead us to consider them as places of assembly (Notroff, Dietrich and Schmidt, 2016: 72).

These enclosures, with their predominance of one animal per building, which we interpret as the apotropaic animal of the clan who kept the building, they could be a species of diverse buildings that symbolize different former clans of hunter-gatherers that became united progressively in time, until the end of the PPNA.

In Göbekli we have several representations of human heads in round bundle on stone, but never appeared shaped skulls like those peculiar of the PPNA of the South Levant. Despite the presence of predators and scavengers among the representations (Notroff, Dietrich, Schmidt, 2016: 77), generally no human remains were found at the site (Notroff, Dietrich, Schmidt, 2016: 66). The only finding of human remains in Göbekli are post-mortem manipulated bones and marks, mixed with those of fauna, found in some of the most recent PPNB fillings (Notroff, Dietrich, Schmidt, 2016: 78); we would suggest that the end of some of the enclosures was done with a ritual filling ceremony including human remains desecrated.

The Göbekli Tepe settlement was built clustered during the older PPNA (layer III), with constructions of a smaller size than in the later stages. Cluster of round buildings close to monumental structures are present in the South Levant as Wadi Feynan examples suggest (Mithen et al., 2011: fig. 3-4).

Later, during the Early and Middle PPNB, Göbekli layer II, 8800-8000 BC (Schmidt, 2007: 271), the architecture was no so "monumental" as before, but on the other hand, they were planed specific buildings sometimes

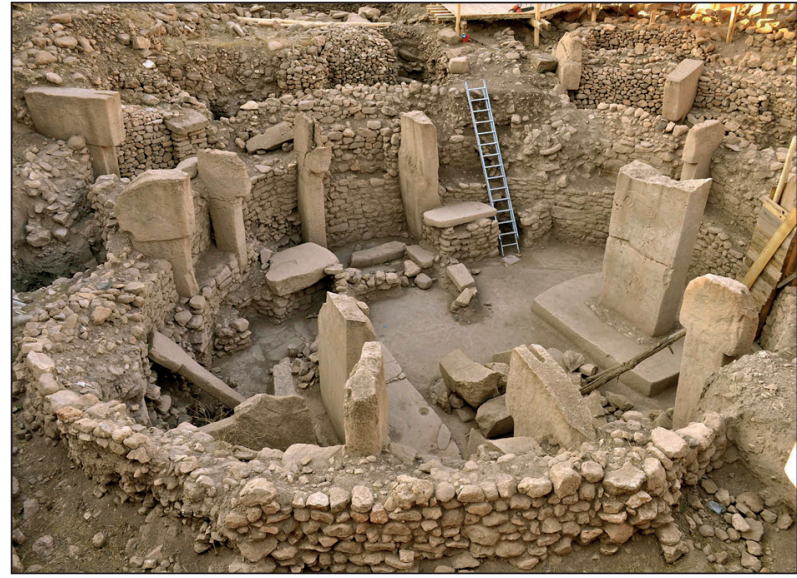

Figure 5b. Gobleki Tepe, Enclosure C, lateral view. DAI.

with rectangular inner space, or rounded corners. In this layer, about half of the buildings featured two pillars of lesser size than in the previous PPNA. With one exception: the biggest building discovered of the period, L1071, yielded thicker limestone walls and six inner pillars; those disposed in a kind of faced-twin pattern (Schmidt, 2010: fig. 2).

Gobekli is more typical of the climax of a society of hunter-gatherers, to the point that its most recent level, Layer II, then with more discreet buildings and pillars compared to the PPNA of the place, would show the decreasing power of these "communitarian" clans of hunter-gatherers in an agricultural world of growing individual ownership. On the other hand, during the PPNB, the lion had a predominant place in the imaginery of Gobekli.

A similar labor force could have been used for the massive stone wall, 1.6-3 m. width and a minimum of 2-4 m.h., and round towers (at least $8.5 \mathrm{~m}$. h.), built at Jericho at the end of the PPNA (Nigro, 2017: 8-9 and com. pers.), in the local Jericho's phase III, $c a$. $+8000 \mathrm{BC}$, according to $\mathrm{C} 14$ dates, but rebuilt at last instance about 7400-7300 BC, in phase VII of Kenyon (1981), interpreted as defensive (Kenyon's “Town wall”) by the early excavators. But Bar Yosef insisted on the ritual and pragmatic character of the constructions, and its pressumed use as a protection against the floods (Bar Yosef, 1986: table 1), a suggestion not supported by topographical and stratigraphical reasons (Nigro, com. pers.) (fig. 6a-6c).

In Northern Mesopotamia during the PPNA and early PPNB, there are sites with mostly special destination (ritual centers) such as Göbekli Tepe or Nevali Çori, while other contemporary sites (Çayönü, Djade, Jef al Ahmar) displayed diverse functions on the same settlement (in spite of the special character of several of those). The material culture seems quite similar, but both types of sites show differences, such as the absence of skulls during the PPNA in Göbekli Tepe. For instance, Göbekli could have been the big ritual center of a hunter/foraging society, per- 


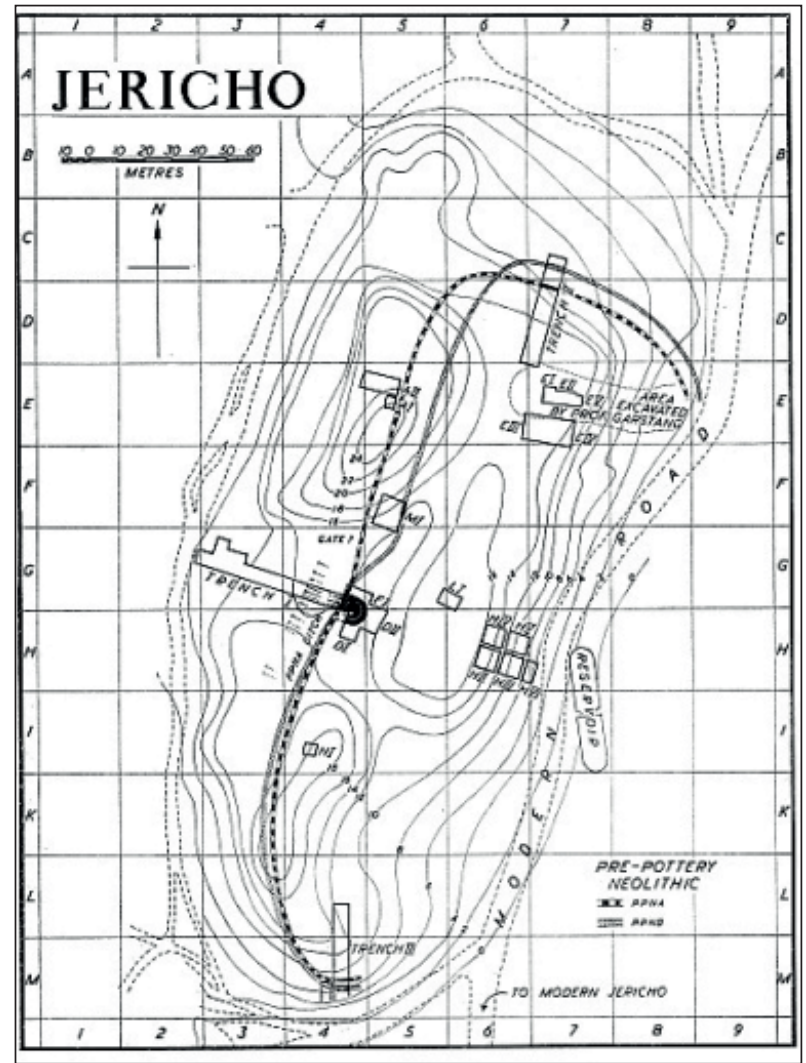

Figure 6a. $P P N A-P P N B$ Jericho, plan (Kenyon and Holland, 1981a: fig. 2).

haps nomads, whom on time later, and because of some "external influences" (v. gr. a likely colonization with peoples from the Levant?), are present on permanent sites with different rituals and beliefs. A proof for this hypothesis could be the abandonment of Göbekli Tepe after the Mid-PPNB, when other Aceramic lifestyles and uses took place. And afterwards, just portions of the "Göbekli PPNA ritual world" remained on a few PPNB sites of the Middle or Upper Euphrates, such as Nevali Çori or Çayönü.

We remark that the appearance and first boom of the Helwan and Aswad arrowheads in the PPNB of the SouthWest Asia coincides with the end of Gobekli IIA (Gopher, 1989: 51-52 fig. 4-5). On the other hand, we presume that the "Göbekli collapse", around mid PPNB, was gradual, as result of a decreasing power (v.gr. the lesser workforce needed for the pillars of the later buildings at Göbekli Tepe II) or a lack of influence of the previous local religious rituals over these societies (which were alterating their former hunter-foraging system). We pressume that after several inner clashes or outer competition, and environmental troubles (as result of a changing climate into a previous slight stressful geography), the managing elites of those sites had to found another way "to keep the balance" of the system and the population under their control. And the old habits and religion were not enough. The end of Göbekli Tepe affected to already well established economic ways of life with different nature. Later on, this could have supposed a cul de sac for the system,

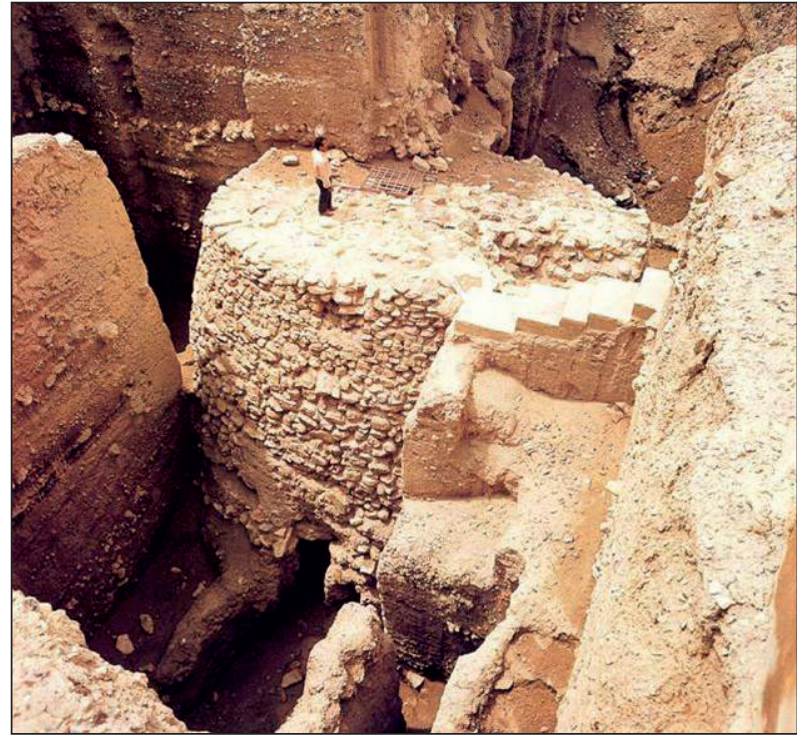

Figure 6b. Jericho tower.

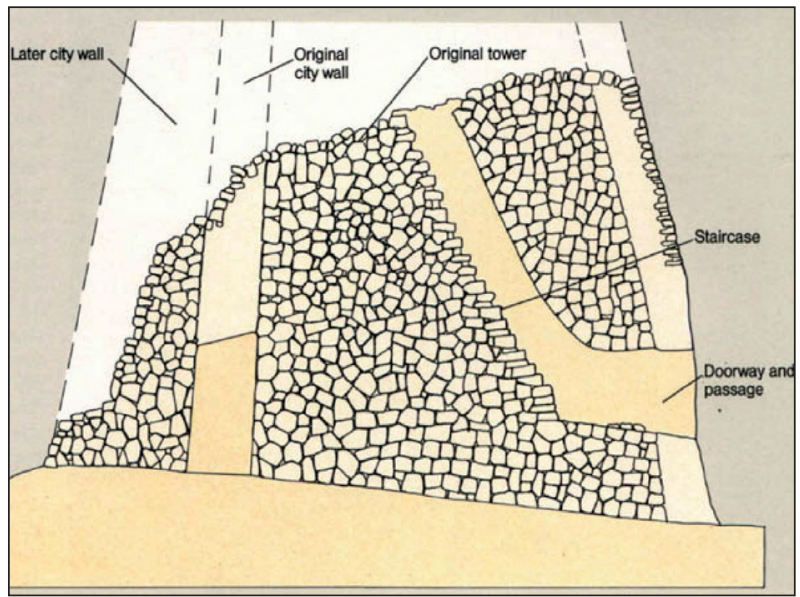

Figure 6c. Jericho tower, north section (Kenyon and Holland, 1981b: pl. 244).

and in such way, the PPN societies became a more global food producing entity (for a similar conclusion Starkovich and Stiner, 2009: 58). A ground for such assertion is the hypothesis formulated by Bar-Yosef (2002) on the South Levant.

Does it assume that domestication was partly a chance to conserve animals within permanent settlements as a survival strategy in the face of an annual forecast of extensive or colder winters? Or was Göbekli Tepe only a place for special rites of hunter clans from societies that had already begun other strategies? Then, Eastern Anatolia could have seen the climax of an organized society of hunter-gatherers from various territories but living in a surrounding world where it began the Neolithic agrarian mentality (meaning the individual possession of the territory versus the community of former hunter-gatherers), and which seems clearer, with these data, to have a certain relationship or origin in the South Levant. 


\begin{tabular}{|c|c|c|c|c|c|c|}
\hline Period & Site & $\begin{array}{l}\text { Approximate } \\
\text { depth of } \\
\text { cultural } \\
\text { deposits }\end{array}$ & $\begin{array}{l}\text { Site } \\
\text { area } \\
\text { (ha) }\end{array}$ & $\begin{array}{c}\text { Estimated } \\
\text { population }^{\text {level }}{ }^{b}\end{array}$ & $\begin{array}{c}\text { Estimated } \\
\text { population }^{\text {level }}{ }^{c}\end{array}$ & $\begin{array}{c}\text { Mean } \\
\text { population } \\
\text { level }^{d}\end{array}$ \\
\hline \multicolumn{7}{|l|}{ Late Natufian } \\
\hline \multirow[t]{5}{*}{ (11,000-10,300 B.P.) } & 'Ain Mallaha (Ic/b) & $<1 \mathrm{~m}$ & 0.2 & 18 & 59 & \multirow[t]{5}{*}{59} \\
\hline & Nahal Oren & $<1 \mathrm{~m}$ & 0.2 & 18 & 59 & \\
\hline & Hatoula $(4 a, b, 5)$ & $<1 \mathrm{~m}$ & 0.2 & 18 & 59 & \\
\hline & Saaĩdé II & $<1 \mathrm{~m}$ & 0.2 & 18 & 59 & \\
\hline & Shukbah & $<1 \mathrm{~m}$ & 0.2 & 18 & 59 & \\
\hline \multicolumn{7}{|l|}{ PPNA } \\
\hline \multirow[t]{5}{*}{$(10,300-9,300$ B.P. $)$} & Jericho & $8 \mathrm{~m}$ & 2.5 & 225 & 735 & \multirow[t]{5}{*}{332} \\
\hline & Netiv Hagdud & $3 \mathrm{~m}$ & 1.5 & 135 & 441 & \\
\hline & Gilgal I & $3 \mathrm{~m}$ & 1.0 & 90 & 294 & \\
\hline & Dhra' & $2.5 \mathrm{~m}$ & 0.45 & 41 & 132 & \\
\hline & Nahal Oren & $2 \mathrm{~m}$ & 0.2 & 18 & 59 & \\
\hline \multicolumn{7}{|l|}{ MPPNB } \\
\hline \multirow{5}{*}{ (c. $9,300-8,500$ B.P.) } & 'Ain Ghazal & $3 \mathrm{~m}$ & 4.5 & 405 & 1323 & \multirow[t]{5}{*}{764} \\
\hline & Tell Aswad & $?$ & 4 & 360 & 1176 & \\
\hline & Jericho & $4 \mathrm{~m}$ & 2.5 & 225 & 735 & \\
\hline & Yiftahel & $1.5 \mathrm{~m}$ & 1.5 & 135 & 441 & \\
\hline & Kfar Hahoresh & $2 \mathrm{~m}$ & 0.5 & 45 & 147 & \\
\hline \multicolumn{7}{|c|}{ Natr Hanoresin } \\
\hline \multirow[t]{7}{*}{ (c. $8,500-8,000$ B.P.) } & Basta & $4 \mathrm{~m}$ & 14 & 1260 & 4116 & \multirow[t]{7}{*}{3293} \\
\hline & 'Ain Ghazal & $1.5 \mathrm{~m}$ & 10 & 900 & 2940 & \\
\hline & Wadi Shu'eib (?) & $4 \mathrm{~m}$ & 10 & 900 & 2940 & \\
\hline & Beisamoun & $2 \mathrm{~m}$ & 10 & 900 & 2940 & \\
\hline & Es-Sifiya & $3 \mathrm{~m}$ & 10 & 900 & 2940 & \\
\hline & 'Ain Jammam & $3 \mathrm{~m}$ & 6-8 (7) & 630 & 2058 & \\
\hline & Ramad I & $?$ & ? & $?$ & $?$ & \\
\hline \multirow{4}{*}{$\begin{array}{l}\text { PPNC/Final PPNB } \\
\text { (c. } 8,000-7,500 \text { B.P.) }\end{array}$} & & & & & & \multirow{4}{*}{3822} \\
\hline & 'Ain Ghazal & $1 \mathrm{~m}$ & 12 & 1080 & 3528 & \\
\hline & Basta (?) & $?$ & $14(?)$ & $1260(?)$ & 4116 & \\
\hline & Ramad II (?) & ? & $2(?)$ & $?$ & $?$ & \\
\hline
\end{tabular}

Figure 7. South Levant PPNA-PPNB settlement size (Kuijt, 2000: 81 table 1).

But on the other hand, on the course of the abandonment at Göbekli Tepe, that took place in the middle of the PPNB, the buildings were filled with wild animal bones (games and gazelles, mostly) and fragments of flint. In addition, there were human stone heads, and traces of human bones (after the most recent excavations there, pers.com.). The fact of finding unfinished pillars in the nearby quarry shows that despite all the odds, the end of the use of the Göbekli Tepe complexes happened in a relatively short space of time, as an unexpected event which took place suddenly.

The "religion" or rituals coming from the South Levant along the PPNB seem more focused on the funerary context and concerning certain idea of property of the territory, that the necessity of a monumental collective building as it appeared formerly, during the PPNA of the Tigris-Euphrates hinterland.

However, we are beginning to know the religious rituals of the Levantine PPNA into a center with monumental structures, especially thanks to WF 16, located in the Wadi Feynan, south of Jordan, 9750-8550 BC; there with the largest exposure for a PPNA site in the southern Levant. On WF 16 appeared two monumental structures: an amphitheater, of elliptical plan, a $22 \times 19 \mathrm{~m}$ structure constructed of pise (so called 075) and a kind of semi subterranean tower that was above it (so called 0100). A wall separated them from other semi-subterranean circular structures, up to thirty, pisé-walled, of modest sizes, with burials, generally individual, containing adult or young men in general, and a few associated to special or imported materials. The structures above were used as workshops or for domestic activities (Mithen et al., 2011: 355 fig. 3; Flohr et al., 2015: 146 fig. 3). In the Jordanian site WF 16 it could be contemplated how a group of people of the PPNA would be realizing public conmemorations or feasting based on agricultural products. In summary, there a center of monumental character displays a collective activity with funeral rites partners already cemented in the concept of private-communal property.

\section{THE AGREGATION PROCESS TOWARDS THE CENTRAL VILLAGES}

The concept of "great" is very subjective for each culture. For the inhabitants of the West Asian Aceramic Neolithic, they were the first to live in permanent settlements and with an agglomeration of a few hundred inhabitants into the big sites: for such a kind of people that just a few generations before such assembalges, their world 
was summed up to 20-30 members and in cooperation with one or two groups like them. After the mentality of a hunter-gatherer society, being in a place with several hundred individuals was a multitude. No doubt, the early Aceramic Neolithic big villages seemed to them as a great city to us today. For their standards of mental structure, these hundreds of individuals would amount to a large and complex gathering, a big place to be managed as a very complex organization.

Big sites, ranged from the 0.1-0.2 ha during the Natufian, and jumped, during the PPNA, to $c a .5$ ha, such as Jericho (Nigro, pers. com.) and 9 ha in Göbekli Tepe. But the numbers had different averages later on, and in Middle PPNB, reached 4-4.5 ha, as in Tell Aswad and Ain Gazal. During Late PPNB, 10 ha (Alt et al., 2013: 2) or 14 ha in Basta and 10 ha in Beisamun (Kuijt, 2000: 81 table 1 and 2008: 293-294 fig. 1-2; Bar-Yosef and Belfer Cohen, 1989a: 61 table 1). At the end of the Late PPNB; 'Ain Gazal reach 15 ha with 2.500 people, v.gr. ca. 167 per hectare (Rollefson and Kalafi, 2013: 6). Such bigger sites were present in the Levant (Tell es Sultan/Jericho), Euphrates (Tell Bouqras, Göbekli Tepe) or in Anatolia (Aşikli), surrounded by smaller places, in summary evidencing similar patterns of settlement across different ecological zones and regions, and suggesting a network of interdependent sites in each specific area or region (Watkins, 2008: 148, 154-155) (fig. 7).

The equation big size and long span of time of occupation speaks in favor of the location of those settlements as centers, at least its function as the core of some kind of informal polities controlling or influencing far distance places and/or access to resources. Some special spots at crucial intersection zones, such as precise valleys or river locations, seem to be the areas in preference for the settling of the Aceramic Civilization of Western Asia. Most of the Aceramic Neolithic biggest villages, such as Aşikli Höyük, Göbekli Tepe, Çayönü Tepesi or Tell es Sultan/ Jericho, are placed at the intersection of different ecologies.

The core sites in the Middle-Late Aceramic B were just big villages, v.gr. over 5 ha, and inhabited by an average of 500-1000 up to 3000-4000 persons (Kuijt, 2000: 81 table 1, 90 fig. 6, 2008: 294 fig. 2; Birch-Chapman et al., 2017: 3 fig. 1). But those sites were able to control the access to resources or materials coming from far regions and thousands of kilometers. A continuous and gradual access for local hunter-gather societies to obsidian sources from Central or Eastern Anatolia since the Epi-Paleolithic period and it must had give a gate to other "markets" or societies afterwards an optimal environmental moment ocurred at the end of the Holocene. The gradual changes in economy, population and society through time made possible that "previous receivers" of commodities, as the Southern Levantine PPNA sites, then increased their role in the trade and control, and so shifting the hands.

Taurus area sites seem to need little area (and less population) to concentrate the activities on any settlement than the Levantine or Euphrates riverine villages. Maybe is due to an expected more mobile character of the populations of Northern Mesopotamia in comparison to other regions during the Aceramic Neolithic.

For instance, the architecture shows clearer changes and developments along this long arc of time. The Aceramic Neolithic is the period when the huts became houses. The early PPNA experienced circular architecture either in the South Levant or in the Euphrates and Tigris areas. But that architecture sometimes could be on stone or mudbricks or another kind of materials (pisè, wattle and daub), on what it seems some kind of technical experimentation, especially in the PPNA phase. The apparition of mudbrick seems to happen as early in the Levant as in Northern Mesopotamia (Aurenche, 1993); and as examples, we have several Southern Levant or Mesopotamian cases, such as Tell es Sultan/Jericho or Mureybet (Cauvin, 1973), and even it is visible on those sites with older phases (Natufian or pre-Natufian in the South). The places with pre-PPN levels (such as Tell Abu Hureyra and Mureybet IA-IB in Syria, Beidha in the Jordan valley or Zawi Chemi Shanidar in North Iraq) are very important to see this evolution. The abandonment of Tell Abu Hureyra during the recent Dryas coincides with the increase of population of Tell Mureybet, $50 \mathrm{~km}$ upstream.

In most of the sites that had circular architecture (the oval constructions in Jericho seem an exception), the buildings were not constructed only in stone walls or big slabs (Göbekli Tepe, Gilgal I), but sometimes on mudbrick, a technological practice used together with other materials such as wattle and daub or pisè (cf. Nahal Oren, Tell es Sultan/Jericho, Mureybet II/IIIA; Gilgal I with its presumed second store buildings of mudbrick in combination with stone), and plastered walls or floors, suggesting some kind of early experiments in developed techniques for the architecture; an important feature for the societies developed after local Epipaleolithic hunter-forager traditions.

There was an initial reluctance of the division into little rooms of the stone architecture during the first stages of the PPNA; earlier Jericho is an exception, and Göbekli Tepe seem to surpass this limitation with some non decorative central pillars in the late PPNA and early-middle PPNB phases. For other regions, the practice was to access to the buildings by a ladder from the roof, a feature kept in use even during the later rectangular mudbrick architecture of the Central Anatolian PPNB (cf. Aşikli Höyük, Çatal Höyük, Musular).

Since the earliest permanent buildings of the PPNA from the South Levant (specially the local Sultanian, with the oval buildings of Tell es Sultan, or Nahal Oren and Gilgal I) or the Syrian Euphrates (Mureybet II), a standard size seems to be present for the houses, 3-5 m. in diameter. Some important changes took place simultaneously in several regions at the end of the PPNA or earlier PPNB, as it is suggested by the internal compartimentation of the circular buildings (Mureybet IIIA). The architectural changes seem to be subtle; according to the evidence from the Euphrates sites: there limestone pieces, pisè 
walls, and foundations with fine sand (Mureybet IIIA) or stone appeared in several buildings of different sites (Tell Sheikh Hassan, Mureybet IIIA, Tell Sheikh Hassan).

There is rectangular architecture at the Late PPNA phase of Jerf el Ahmar (Stordeur, 1999). Also rectangular architecture is already well present in the Middle Euphrates sites during the PPNB (Mureybet III, Tell Sheikh Hassan) (Cauvin, 1980; Ibáñez ed., 2008). Olivier Aurenche (1981) suggested that the architecture from the Taurus PPN derived from Syria. Also the specific contention walls technique was present on the area, but not into the circular buildings of the PPNA. But Southern Levantine sites had just that kind of rectangular buildings since the local PPNB. During the PPNA, in the Middle Euphrates settlements close to the river bench (Tell Bouqras for instance), there was an early use of mudbrick architecture for rectangular buildings, which suggests an early experimentation with clay. Could it have been the rectangular architecture an influx to Southern Levant from Euphrates or central Anatolian areas? The obsidian travel could have made it possible as an additional traded commodity, due the early exchanges between the South Levant and Eastern Anatolia, and later, during the PPNB, among Central Anatolia and the South Levant.

Rectangular architecture occurred in the Taurus piedmont (Çayönü Tepesi), also since the latest phase of PPNA, Early Grill, as it was in the Central Anatolian site of Aşikli. The initial phase at Çayönü, consisted of circular architecture. Çayönü, on the junction of three zones, is close to the Ergani plain, the Taurus mountain ranges, and in the vicinity to the Diyarbakir basin. It is a flat and oval shaped mound of $160 \times 350 \mathrm{~m}$, and had a maximum occupation extent close to 3 ha.

On the earliest occupation level in Çayönü, the Round Building, 10.200-9.400 BC, PPNA, there were not permanent structures, a clue for the presence of population with nomadic roots, as in Suberde (Bordaz, 1973), Hallan Çemi (Rosenberg, 1992 and 1999), 10.700-9.200 BC; or Qermez Dere in the Zagros area (Watkins, 1990), all those sites settled before the real mid-PPNB end of Göbekli Tepe, which seems the southernmost site connected to that regional variation of the PPN. The first sub-phase of Çayönü shows the use of different materials for the houses construction: stone, wattle and daub, or clay and pebble as external reinforcement.

Çayönü does not show any hiatus between the circular architecture and the Grill plan sub phase buildings of the late PPNA and early PPNB. The plastered floors helped to insulate the constructions during the hard months of the winter. After the Early Grill, Late PPNA, appeared the Late Grill plans at Çayönü, $c a$. 8400-8200 BC, early PPNB, buildings which were constructed to avoid flooding (Ozdogan, 1999: 42), but its upper structure could have been oval (Ozdogan, 1999: 43, n. 23). The grill plan appeared also in the early PPNB of Dja' de, contemporary with Çayönü examples.

The Channel Building, also called the Intermediate phase of Çayönü, with important architectural improve- ments, could be a reflection of the social changes and new elements coming into the site. This was the first subphase at the site with one specific building of particular use, then the Bench Building, maybe related to the slightly later in date, the Flagstone Building, but of the same phase. Perhaps the Çayönü's Intermediate phase is a good tracker to search the clues for those developments, when a ritual building, full of skulls and human remains appeared for first time, and likely later it was replaced with a different ritual building, the Terrazzo Building, similar to some Nevali Çori structures, Gebaude II and Gebaude III. Both displayed the T-shaped pillars or twin central monoliths with anthropomorphic reliefs, typical of the Göbekli Tepe buildings (Hauptmann, 1993: fig. 7-12, 15). On the last stage of the phase, the Skull Building was erected and further reconstructed during a few generations. After our interpretation, the sudden appearance of the first Skull Building in Cayönü, which appears to have been constructed in a hurried way, may be a reflection of the emergence of new leaders in charge of this central town, with a religion based on human sacrifices.

On most of the Southern Levant or central Anatolian sites it is hard to note the difference between domesticity and special buildings used for other different activities (mostly ritual), K. Kenyon single out several "cult houses" (Kenyon, 1981). Since the Mid-PPNB, the big sites south of Taurus piedmont (Nevali Çori or Çayönü), yield some new structures monumental in appearance, and with a clear ritual use (Hauptmann, 1993: 39). We remark that on Çayönü Tepesi every level of each sub-phase had one special building (Bench Building, Flagstone Building and Skull Building at the Intermediate phase, and the Terrazzo Building during the Cell-plan phase (Schirmer, 1983; Bicakçi, 1995), with a specific function; and the same happened at least in Nevali Çori Schicht 3, the oldest phase of that site (Hauptmann, 1993: fig. 4). It could have been an inheritance from the former lifestyle, based on mobile populations gathered around ritual centers.

Çayönü Cell Building phase, Late PPNB, had a lifespan of 7800-6800 BC, where the architecture had an arrangement in a sort of small square rooms (the so-called cell plans). Cayönü's big square, in the eastern part of the site, began to be used in the last phase of the Skull Building (Ozdogan, 1999). The square had a pebbled surface. It was an area of $1000 \mathrm{~m}^{2}$ with communal activities, such as meetings, but also carnage and throwing of rubbish. The Cell planned buildings are also contemporaries in use with most of the life of that square; those buildings consisted of larger houses, with floors paved in stone (Ozdogan and Ozdogan, 1989).

Cafer Höyük was settled on virgin soil (level XIII) but without recognizable traces of architecture, except hearths. Cafer Level XII was dated ca. 8300 BC (Cauvin et al. 1999: 90, 100). Level XII buildings have similarities with the Çayönü PPNB examples from Grill plan and Intermediate phases. No gap separated both levels in the settlement. Cafer Level XII had rectangular architecture built on mudbrick and stone foundations, a different tech- 
nique from the later Cafer Level $\mathrm{X}$, prior to the Middle PPNB, when a more complex plan, tripartite, was built with large moulded mudbricks, whose standard size, 90 $\mathrm{x} 25 \mathrm{~cm}$, is the same as the Late PPNB tripartite building from El Kown (Stordeur, 2000).

The excavators of Cafer Höyük believed in a periodical renovation of the architecture for the two earlier PPNB phases at the site (Cauvin et al., 1999: 93), Cafer III, 83008000 BC and Cafer II, 8000-7500 BC (de Moulins, 1997). The earliest phase of Cafer Höyük seems to correspond with the cobble-paved/Intermediate phase of Çayönü (Cauvin et al., 1999: 101).

On the oldest phase, Cafer VIIIa, yielded structures still with roundish buildings, in spite of several cell plans, which were used for storage (Cauvin et al., 1999). The presence of the outer ladder links Cafer Höyük to the Çayönü Intermediate phase. The silos were used again during a following phase, Cafer Level VI. The latest phase of the site showed changes in the organization of the architectural space, when large cell-plans, similar to the Çayönü examples, appeared. There was a burning of structures during the Cafer level IVc.

The presence of other silo-like structures on far distant areas, during the Middle or Late PPNB, such as Tell Sheikh Hassan (Cauvin, 1978), could be an evidence of hard times or just a concentration of surplus in a few hands. The storage was not on domestic scale for some specific sites, and the archaeological record show clues for some kind of crisis, and perhaps suggesting sometimes a demographic decrease (Brami, 2014: 47-48, 162). Ovens for the processing of collected grains are present either in the Southern Levant (v. gr. Nahal Oren) as in the Euphrates area (Mureybet IIIB).

In Aşikli Höyük, there was a mound of 4.5 ha (Esin and Harmankaya, 1999: 118; Özbasaran, 2011: 37 and 2012), placed in a tributary Melendiz Çay, about $50 \mathrm{~km}$ from the sources of obsidian of the Gollu Dag in Ciftlik. In Aşikli Höyük were dated several moments such as the level $5 \mathrm{ca}$. 9000 BC, upper level 4, 8400-8100 BC, and level 2, 80007500 BC, Early-Middle PPNB (Özbasaran, 2011: 31 table 1; Stiner, 2014: 8404-8405, table S1). Early levels here already had rectangular mud architecture, plastered in red in various cases (Esin and Harmankaya, 1999: 129). The mud for the buildings at Aşikli Höyük could be collected at the close salt lake. Several rooms were grouped as clusters forming an unit, and maybe ocurred alterations into the familiar social structure as it is suggested due to inner changes into the building rooms (Esin and Harmankaya, 1999: 128) (fig. 8a-8c).

At Aşikli there are buildings without the usual residential use, which were interpretated as public because of their size (reaching sometimes $500 \mathrm{~m}^{2}$ ) and thicker walls, plenty of rooms and interior courtyards. Also in central Anatolia, the earliest building on Musular was a mud brick

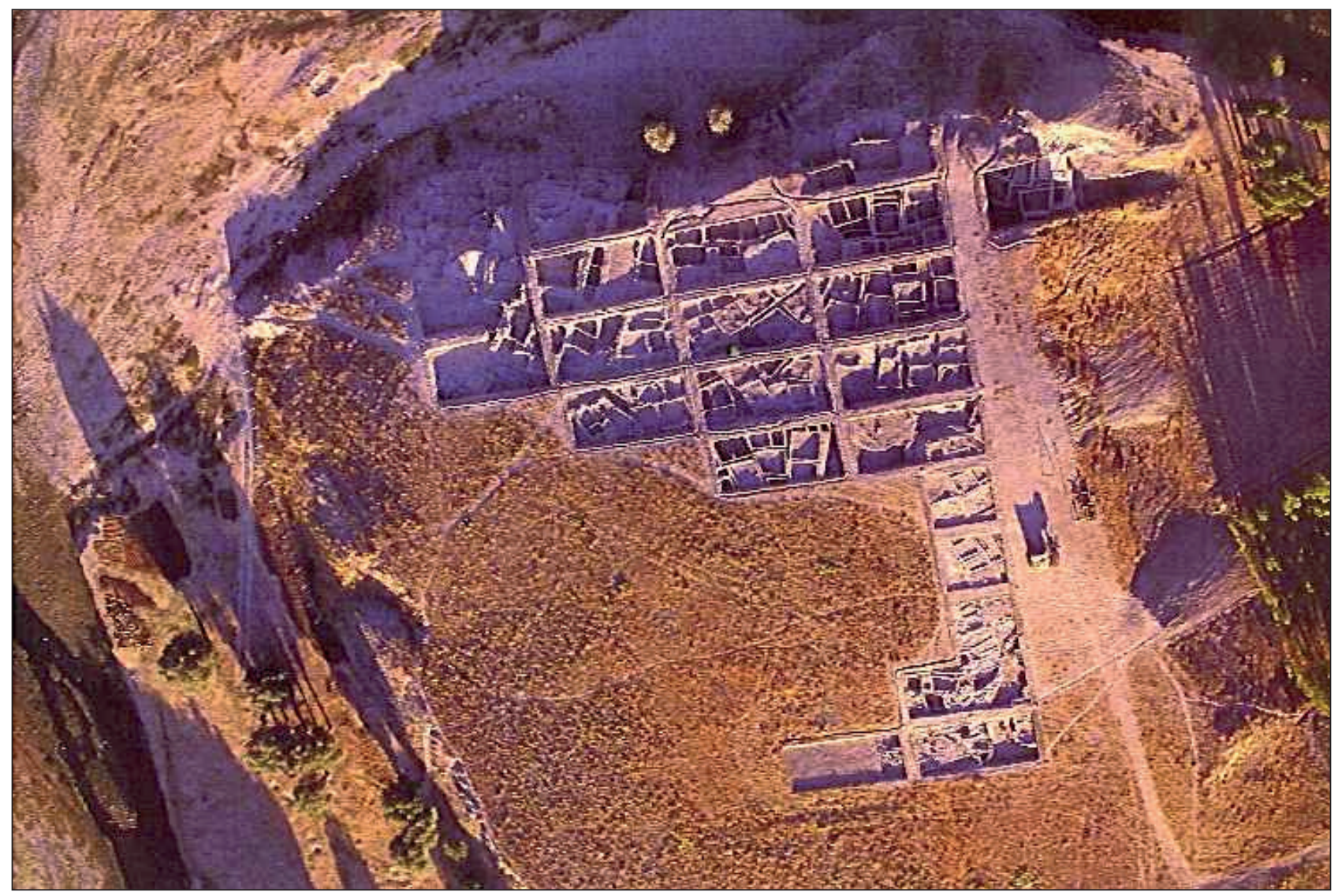

Figure 8a. Aşikli Höyük, aerial view. 


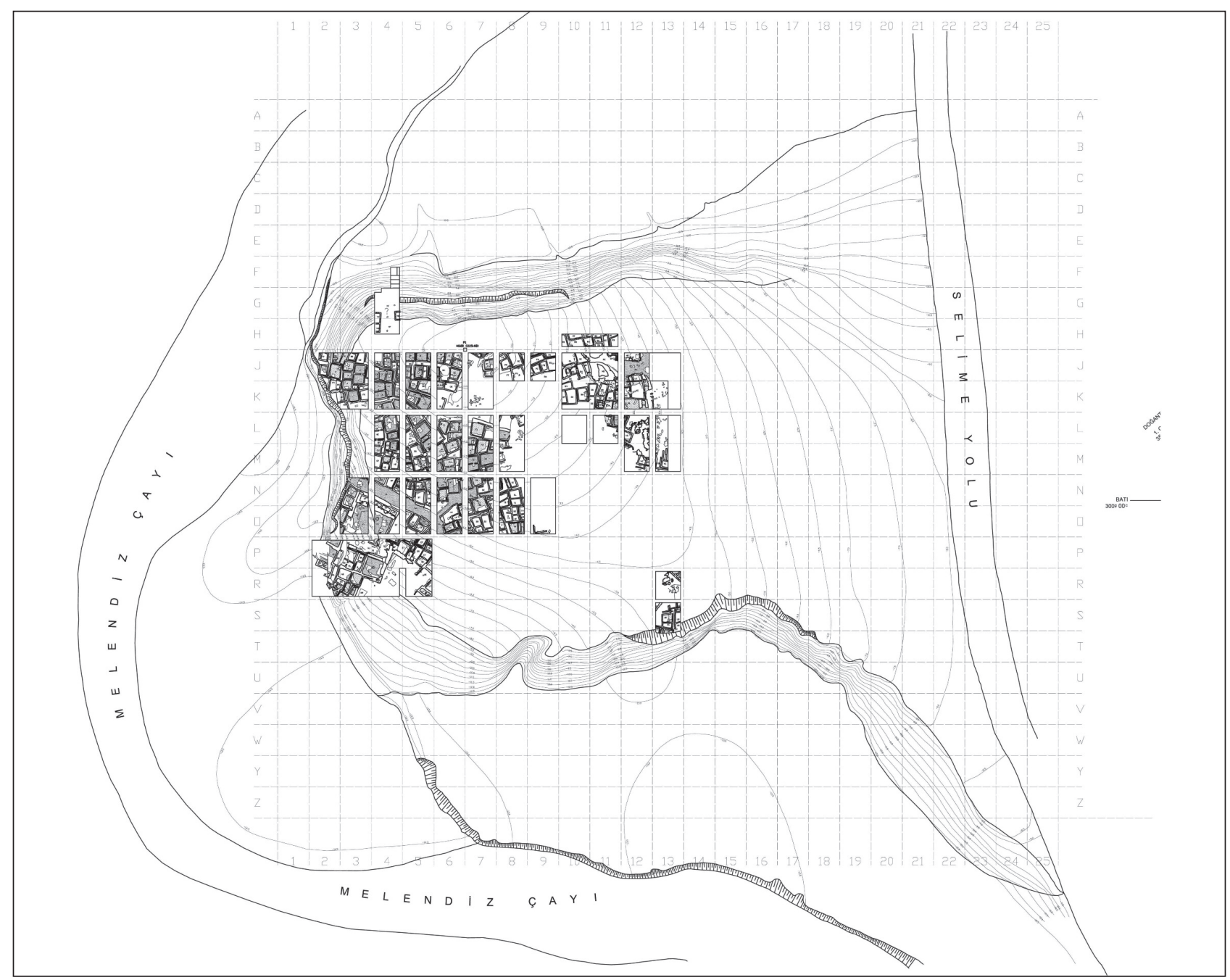

Figure 8b. Aşikli Höyük, PPNB, topographical plan (Özbasaran, 2011: 29 fig. 2).

construction with plastered walls and red painted floor, the Building $A$. That was a non-domestic building, and looks like Building $T$ at Aşikli, interpreted as a temple by the excavators (Esin and Harmankaya, 1999).

Abu Hureyra is currently under the reservoir lake of Tabqa, in the Euphrates. Although during the time of its discovery, was on a plain $1 \mathrm{~km}$. to the south of the Euphrates and in an area with $200 \mathrm{~mm}$ of annual rainfall. In the oldest archaeological phase excavated at Hureyra, of PPNA date, there is rectilinear mudbrick architecture, placed as a cluster, using the same foundations of previous buildings, for the new constructions, a phenomenon observed also in Tell Bouqras. There was no differentiation between the functions of the buildings, according to the contents. During the local Tell Abu Hureyra Middle and Late PPNB phases, Abu Hureyra 2A 8500-7500 BC and Abu Hureyra 2B, 7500-6000 BC (de Moulins, 1997; Moore, Hillman and Legge, 2000: 257), the place reached its maximum expansion, up to $12 \mathrm{ha}$. The settlement followed then the arrangement of cluster constructions of the PPNA phase. The architecture displayed the use of mudbrick buildings with small standardized rooms.

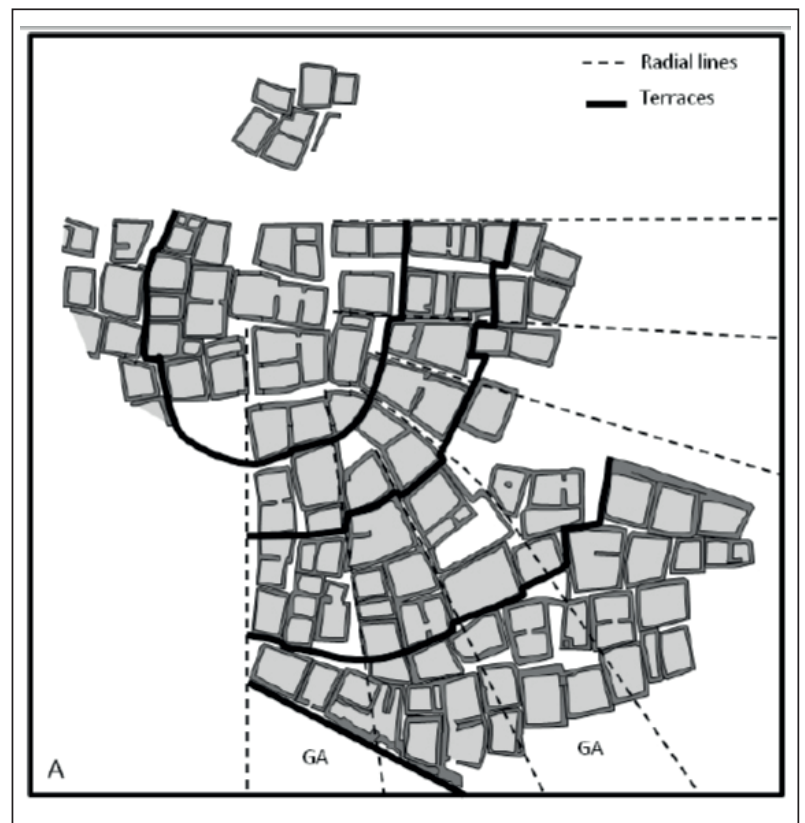

Figure 8c. Aşikli Höyük, terraces and radial lines (Brami, 2014: 190 fig. 24a). 
The rise of a kind of "Jericho system" into the Southern Levant, because it seems clustered around Tell es Sultan/ Jericho, a settlement of 2.5 ha, seems to coincide with the twilight of the Göbekli Tepe center, placed not far from the Taurus piedmont. We suppose after the dates that both mentioned central sites coexisted for a short time, Göbekli Tepe from 9100 until 8100 BC, and Jericho from 8300 until $7300 \mathrm{BC}$. And it is not by chance that after the (gradual?) collapse of the Göbekli Tepe "best of times", then rised the stronger Aceramic Neolithic links between central Anatolia and the Levant.

In the South Levant region, time after the start of the Jericho VII phase, on a couple of generations at most, some fire plus the apparition of a new ceremonial structure took place in phase VIIIB (Bar-Yosef, 1986: table 1 BM-110 and BM-1789). But those new changes at Tell es Sultan/Jericho proved unsuccessful, because the Aceramic Neolithic site did not last centuries: it fell out of use after the phase Jericho XI. Contrary to the military hypothesis ("enemies against Jericho"), some scholars accepted the vicinity of a wadi as a meaning of erosion risk and would be an alternative explanation for the building of those massive structures (Bar Yosef, 1986). But that alternative hypothesis does not explain the presence of massive towers, as a simple ritual element; also the increase of lithic arrowheads in the material assemblage and the changes in architectural organization after "Town Wall III" point against this erosion hypothesis. Some settlement gap even took place in Jericho between the PPNA and PPNB periods. The lack of settlement at Jericho during the Late PPNB could be guessed after expected environmental pressures that forced the settlers to leave, maybe in direction to 'Ain Gazal (Bar Yosef, 1986; Rollefson, 1989).

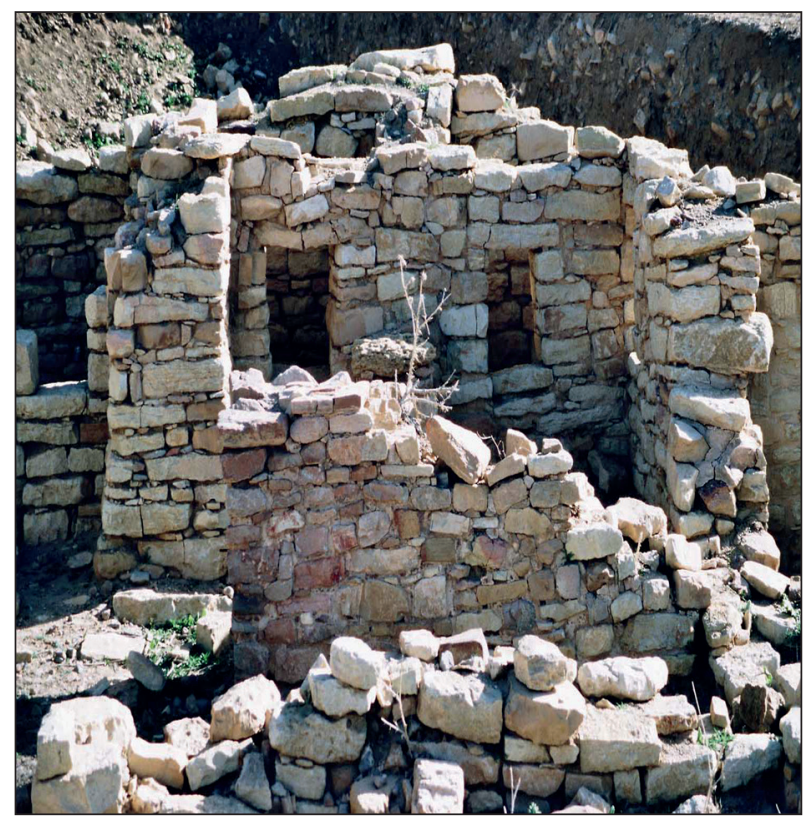

Figure 9a. Basta, PPNB, area B, house.
Beisamoun, with 10 ha during the Late PPNB (Bocquentin et al., 2014: 6), is located in the Hula Basin, middle sector of the Jordan Valley of Israel, with abundant aquifers. The Beisamoun architecture is rectilinear, with floors plastered in lime. In sector E, with the multicellular house 306 , there was a structure with large stone walls in its northwestern sector: the floor had a pavement of pebbles and shells. The plan showed several rooms, and two entrances in opposite parts of the building (Bocquentin et al., 2014: 25, 29 fig. 20).

The modern Basta destroyed part of the Aceramic settlement of the Neolithic period; the place reached 14 ha of occupation during the Late PPNB (Alt et al., 2013), and placed in the access to a wadi, in the south of Jordan. In the south sector standed a rectilinear building with large rooms, $4.5 \times 9 \mathrm{~m}$., and differentiated two floors, one in its southern half plastered with clay, and the other one on its northern sector under the ground, paved with earth and stones (Gebel et al., 1988) (fig. 9a-9b).

Ain Gazal, on the Wadi Zarqa, Jordan, was located on a river terrace, in the intermediate zone between the Mediterranean forest and steppe. The Neolithic settlement begins during the Middle-Late phase of the PPNB, 8500$6900 \mathrm{BC}$, when it would occupy about 14 ha, and had a population of circa 2000 inhabitants (Rollefson and Kafafi, 2013: 3). Ain Ghazal yielded rectilinear architecture, arranged individually, in two or three rooms, each one of larger size ( 5 x $5 \mathrm{~m}$ on average) compared to later periods. There was at least one circular hearth per building, placed in the centre of a room. The buildings seem fully organized according to their East-West orientation. The walls were plastered with lime, from time to time, and some were painted with red ochre, and zoomorphic or geometric motifs (Rollefson, 2000) (fig. 15a-15b).

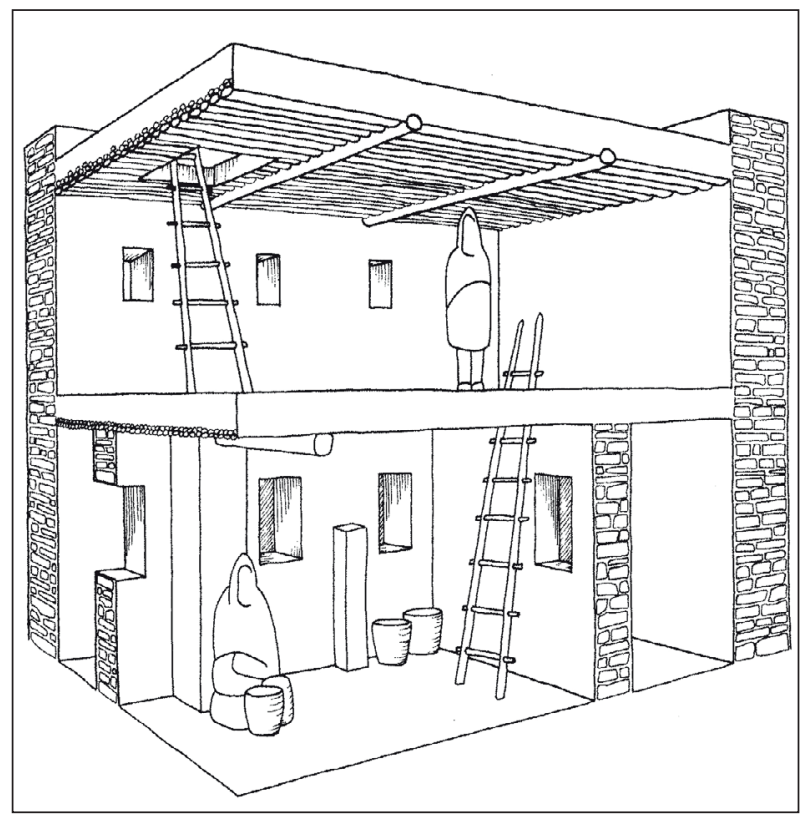

Figure 9b. Basta, PPNB, area B, two floor house, reconstruction proposal (Kuijt, 2000: 92 fig. 8). 


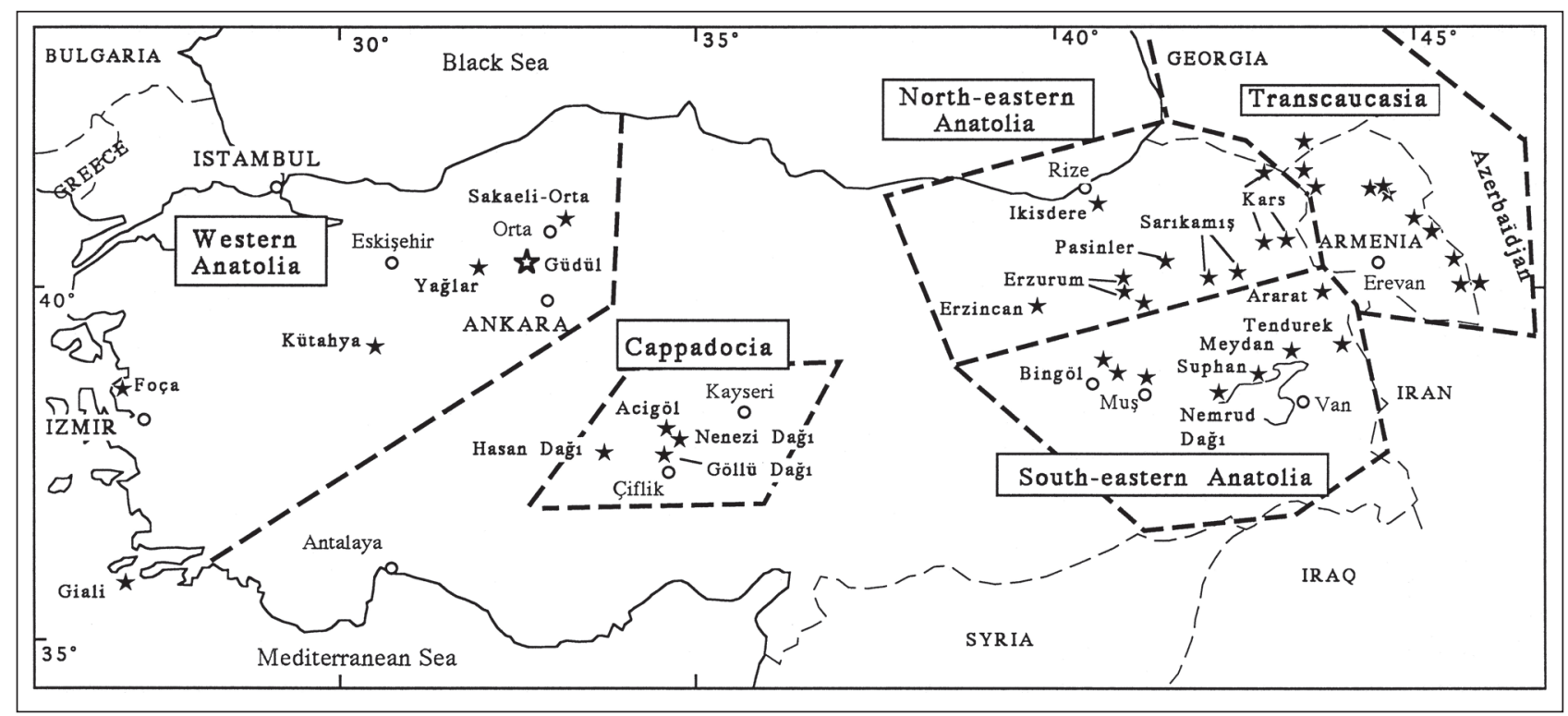

Figure 10a. Anatolian obsidian sources (Chataigner et al., 1998: 519 fig. 1).

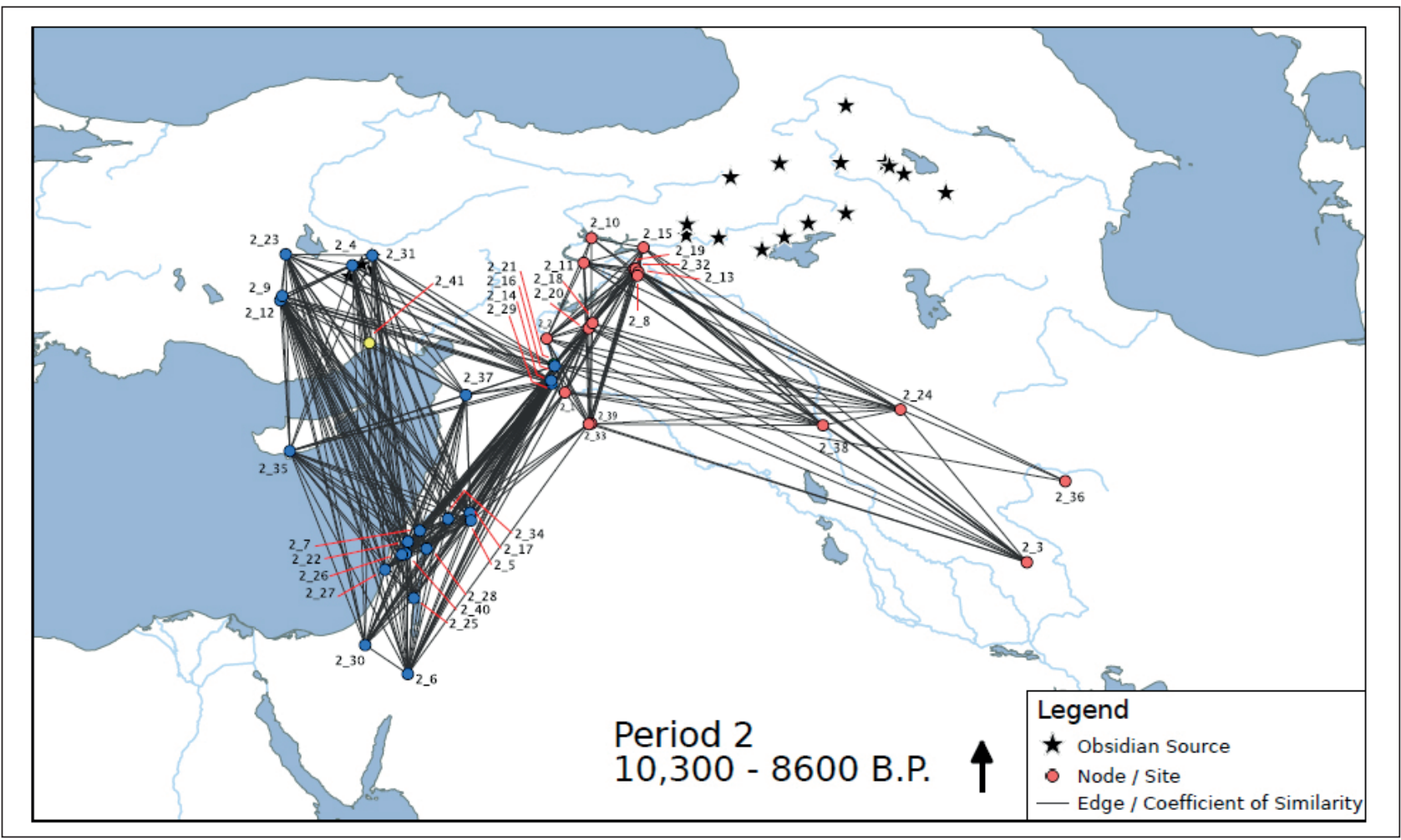

Figure 10b. PPNB obsidian network (Batist, 2014: 94 fig. 7.5).

4. The Central Villages AND THE CONTROL OF LONG DISTANCE EXCHANGE

The best evidence for a long distance exchange during the Aceramic PPN is the spread of the obsidian, a raw material key for the elaboration of projectile points and knives, and with an utility not only for hunting but also for inter-community conflicts. The obsidian had a limited geographical distribution such as also of cores suitable for efficient knapping, avalaible mainly from precise sources in central and eastern Anatolia (Chataigner et al., 1998: 519 fig. 1). Some of the biggest settlements (Aşikli Höyük, Göbekli, Tell Mureybet, Jerf el Ahmar, Tell es Sultan/Jericho), were able to hold the control of some resources as obsidian from the two main source areas, Nenezi Dag in Central Anatolia and Bingöl en Eastern Anatolia (Chataigner et al., 1998: 522 fig. 3, 531 fig. 7) (fig. 10a-10b). 
The traditional view has explained the mechanisms of obsidian exchange using the down-the-line model, searching a decrease in the quantity of obsidian from the source of origin, transported either by hunters using temporary campsites or itinerant craftsmen (Renfrew, Dixon and Cann, 1968; Renfrew, 1977; Cauvin and Chataigner, 1998). However, larger quantities of obsidian would be observed in the southern and eastern extremities of the Levantine corridor, but it was not the case (Ibáñez et al., 2015: 3). In contrast, preferential exchange with neighboring communities was the prevalence during the PPNB, with the interaction of distant nodes or big villages thought few intermediary steps, with preferential attachment of hubs that had access to larger quantities of obsidian (Ibáñez et al., 2015: $4,6)$. It suggests an incipient site hierarchy regarding the obsidian exchange because in case of bigger size of the site, a higher proportion of obsidian was contained (Ibáñez et al., 2015: 5-6). The lack of the obsidian in the northern Levant but its archaeological record in Cyprus, as Akanthou-Arkosykos probes (Sevketoglu, 2008: 67), also point toward a maritime transportation to central and southern Levant (Batist, 2014: 91). In terrestrial routes, together with local circulation between neighbors and allies, must have developed expeditions of $c a$. 15 persons, twice a year, as suggested by ethnographic examples from Irian Jaya (New Guinea) (Pétrequin and Pétrenquin, 1993) and arranged marriages to establish alliances between distant partners (Ibáñez et al., 2015: 9) (fig. 11a-11c).
The blade technology was very spread through Central and Eastern Anatolia and the South Levant. The lithic industry shows conservative traits for a long period (including naviform and bipolar cores, burins, long blades, and arrowheads during the PPNB) but also homogenous changes in most of the affected regions when certain innovations ocurred, from time to time. We noted a scarcity or restriction of flint production during the whole Aceramic period, in concrete during the earlier phase, PPNA, and most of the PPNB, as some kind of challenge to the overwhelming specialization of the Aceramic lithic industry (Astruc et al., 2003: 73; Nishiaki, 2000) and diversification of the production of tools through the Late PPNB, and in special during the last stages of the period; an amount which surpassed the needs of the settled communities. According to some researchers, after a diversification in the concentrations of lithic tools, it is suggested the presence of different economic strategies during the period (Astruc et al., 2003).

Göbekli Tepe's obsidian comes from four different volcanic zones, placed at long distance, at Central Anatolia, Lake Van and Bingöl (Notroff, Dietrich and Schmidt, 2016: 73), suggesting different possibilities such as pilgrimage from these areas of people with access to these goods, or at least the existence of a close chain of intermediaries during the PPNA.

Differences could be appreciated in the obsidian tool techniques or characteristics during a specific period, Late

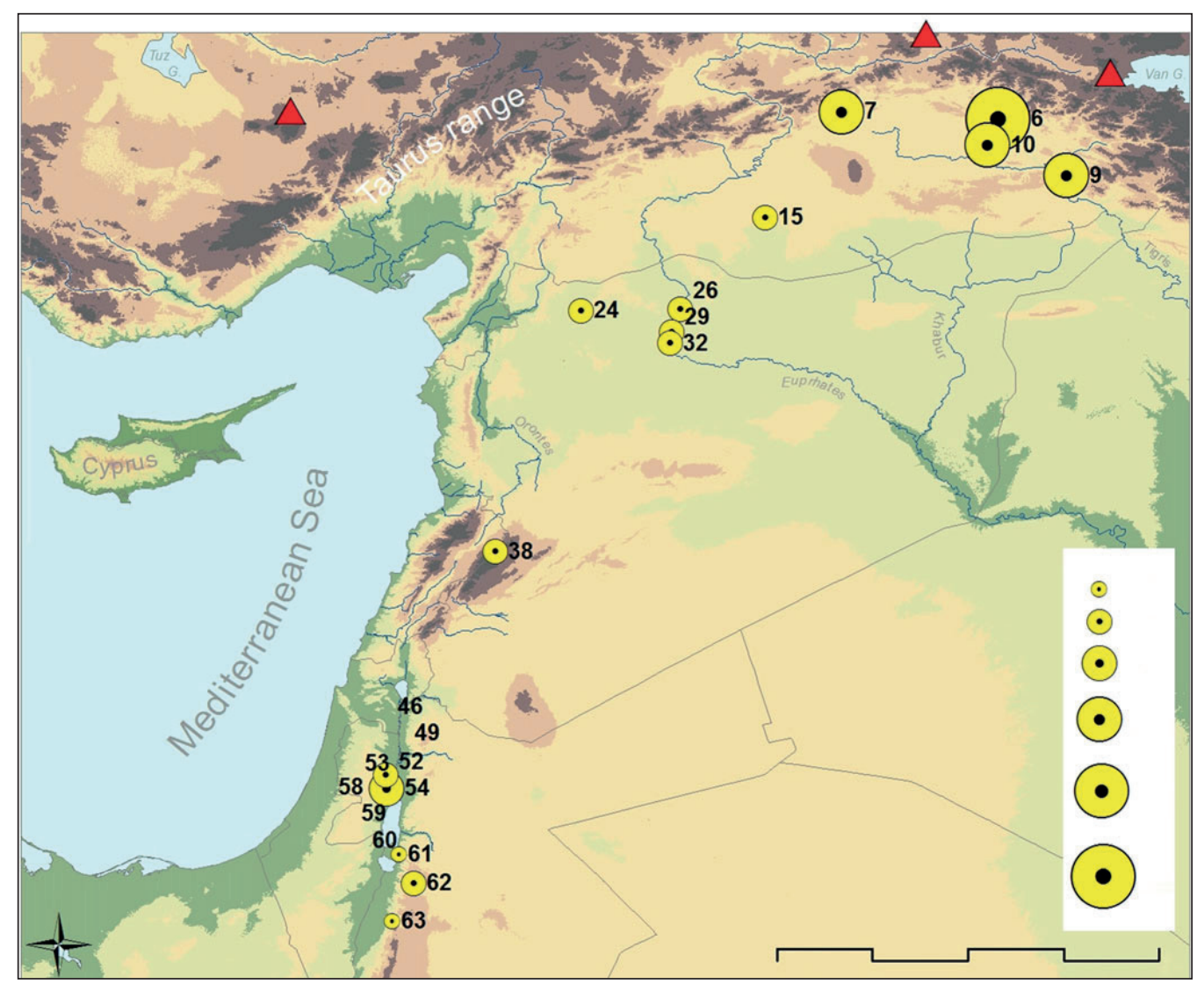

Figure 11a. PPNA obsidian distribution (Ibáñez et al., 2015: 2 fig. 1). 


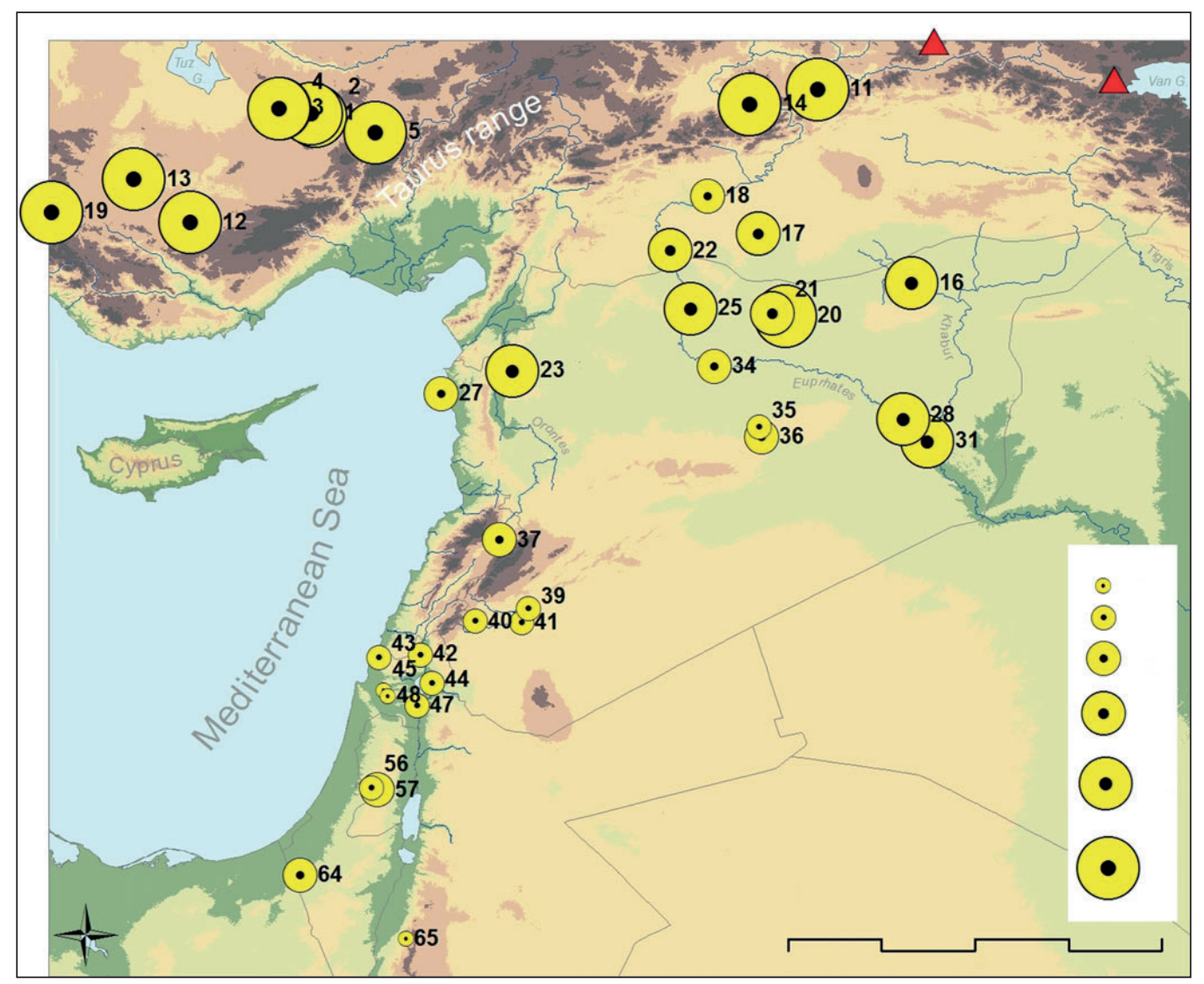

Figure 11b. PPNB obsidian distribution (Ibáñez et al., 2015: 3 fig. 2).

PPNA and PPNB, but it does not mean an absence of the commodity on the "peripheral" regions (Astruc et al., 2003: 72-73). The obsidian "lithic tools' treasures" (meaning a "hidden" bulk of tools found on dailylife contexts) are rare during the Middle Euphrates PPN; on the other hand, large amounts of obsidian per site were spread in other far distant areas (the Levant, Central Anatolia or Taurus and Zagros region sites). Obsidian tools are quite abundant in south central Anatolia (Connolly, 1999), but certain flint tools were a traded commodity for other distant lands, and so a valuated commodity during the PPNB. An example is the absence outside the riverine areas, of chocolat-color silex tools, originally coming from Middle Euphrates contexts, for example Akarçay items (Coskunsu, 2002; Astruc et al., 2003: 74, n. 73). In the Middle Euphrates there was a strong presence of bipolar cores since the earliest moments of the PPNA (Arimura et al., 2000), revealing a suitable area for the interchange of certain flint products.

The obsidian at Çayönü increased during the later levels, since the Intermediate phase, being in equal amount to the other percentages of flint stone materials in the archaeological records. The obsidian of the area comes from the Van region (Eastern Anatolia). During the Late PPNB, sites in the Taurus foothills such as Cayönü or Hayaz Höyük (Roodenberg, 1989) display the high amount of lithic tools and débitage produced locally, which sur-

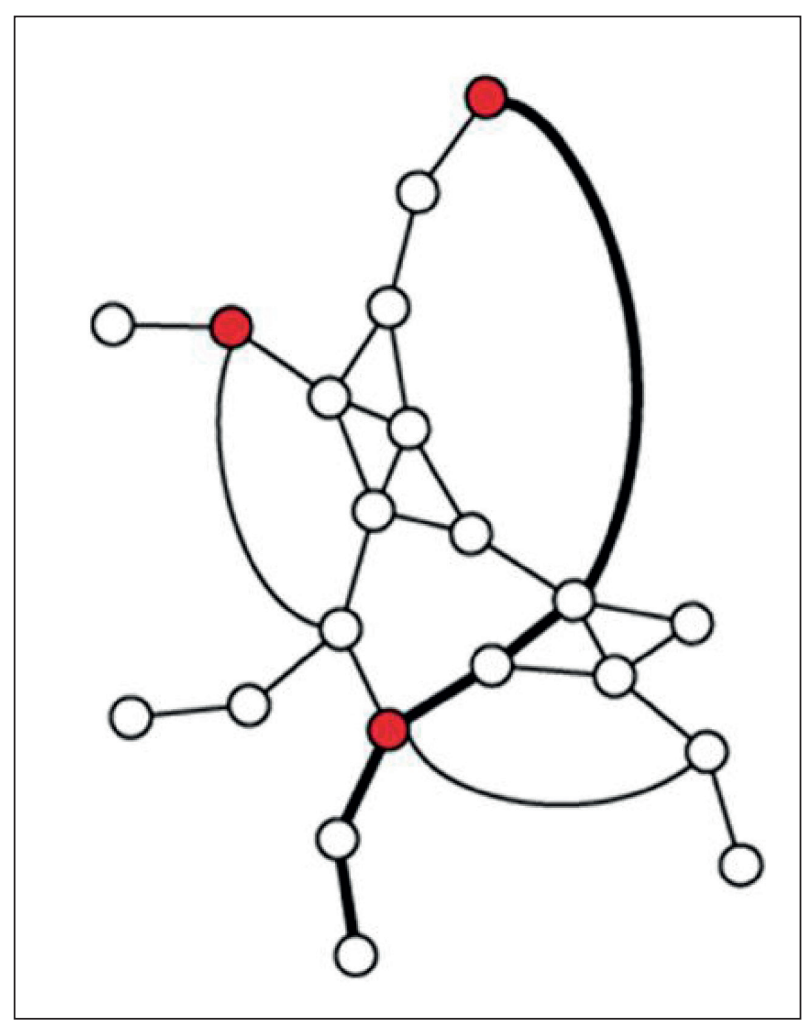

Figure 11c. $P P N B$ complex networks in the obsidian trade between big villages thought few intermediary steps (Ibáñez et al., 2015: 4 fig. 3c). 
passed the needs of the population of those villages. For instance, $90 \%$ of the lithic tools at Suberde were made of obsidian, and where the latest PPNB layer afforded mostly arrows, sickles and large amounts of débitage (Bordaz, 1973). Hallan Çemi has plenty of obsidian artifacts, from eastern Anatolia, and débitage into the lithic bulk (Rosenberg, 1999). In Qermez Dere, very few artifacts of obsidian were found (Betts, 1994), and it suggests imported items.

Half of the lithic industry at Cafer Höyük is obsidian and there most of the ornaments are made of this material, what suggests an orientation of the Cafer economy toward the obsidian trade. During the earliest levels of Cafer Höyük, the closest obsidian provenances for the site were in Bingöl, $200 \mathrm{~km}$ northeast (Cauvin et al., 1999: 99). But for the upper levels, the obsidian came from another different location in Bingöl and from Nemrut Dag area. There is a high percentage of microliths (a main difference with the South Levant lithic industries), or the "Cafer" arrowheads, typical of the Taurus area. At Cafer Höyük there are "Byblos" and oval points, both characteristic types of the Northern Syrian PPNB. Some of the lithic findings at Cafer Höyük suggest closest parallels with artifacts from the southern Levant. The lithic industry of the middle PPNB phase of Cafer had a change of percentages, increasing then the obsidian but decreasing the flint microliths; since Cafer level VI onwards, "Çayönü” obsidian tools appeared. Obsidian prevails on the lithic tools of the last phase of Cafer Höyük, but projectile points such as the Byblos examples were made also of flint.

At the Central Anatolian site of Aşikli Höyük, the prefered raw material for the lithic industry was the obsidian. In this site, among the lithic tools, the arrowheads were very limited, and with gradual changes, but just a portion seem used as weapons (Esin and Harmankaya, 1999: 128), same as in the Middle Euphrates or certain Southern Levant sites (Borrell, 2006: 307, note 353; contra Khalaily et al., 2011: 392). The scrapers are the most used tools on the site (Özbasaran and Özbasaran, 2011: 33). From Aşikli Höyük, Mount Göllüdag obsidian is supposed to have been shipped, not only to the Levant, even North Mesopotamia and Cyprus (Balkan-Atli and Cauvin, 1997); the workshops and dumped materials on site are a conclusive proof.

Musular, in central Anatolia, had a PPNB material culture made of the "pressure flaked" technique, based on the flint blades and the obsidian projectiles, despite the rare flint material; because there were only twenty flint pieces after the record, probably imported (Ozbasaran, 1999: 152). Musular became a blade industry, when the naviform tradition arrived. The projectiles were very numerous, and belonged to a technology, called "unifacial pressure retouch oval shaped" technique, that seems to belong to central Anatolia, in places like Asikli, Can Hassan III or Çatal Höyük (Ozbasaran, 1999: 152).

The obsidian workshop of Kaletepe, closer to Musular, yielded obsidian materials, such as the blank for projectiles, which suggest connections either with the PPNB of the Levant or Southeastern Anatolia during the same period (Balkan-Atli et al., 1999: 142), indicating a possible network operating then in Central Anatolia, with a trade market centered on those distant regions. The needful organization for such demand implied a whole system controlled by a few sites at the extreme of the network.

The percentage of obsidian in the North Syrian coast or Southern Levantine sites increased at the end of the PPNB, as Rash Shamra IV suggests. But all these commodities, seem to come then from the Çiftlik area of Central Anatolia (Khalaily et al., 2011: 392), and no from Eastern Anatolia anymore. At the period, the interchange network of the Taurus area seem to be restricted to the Northern Mesopotamia, Zagros or Western Iran regions.

In Abu Hureyra, the obsidian tools appear in less than $4 \%$ of the total lithic bulk, but they were made on the settlement, and six different sources were identified, from three distinct regions (Van, Bingol and Ciftlik), although mostly from eastern Anatolia (Moore, Hillman and Legge, 2000). Tell Bouqras, a tell of 2.75 ha, located south of the Euphrates was placed into a marginal territory, with annual rainfall of $125 \mathrm{~mm}$. There is little obsidian there, and it came from the Southeastern Anatolian Nemrut Dag (Urfa), however it represents $7 \%$ of the total lithic bulk of the site, a number closer, even bigger, to the Abu Hureyra percentage (Akkermans, 1982).

The comparison of Southern Levant PPN lithic sequences and cultural contexts to the Northern Mesopotamian bulk, evidences certain similarities but, for sure, some local variations. If they show those peculiarities due to regional cultural variants or because different economic or societal structures, is still an issue to be researched in further field work on both regions.

The very little presence of obsidian in specific Southern Levant sites (Beidha V-II) (Byrd, 2005) could be explained as result of a monopolistic control on this trade in the region (perhaps by a polity connected with the Jericho of the period). The three obsidian tools present at Beidha had a curious origin; the oldest tool, from Beidha $\mathrm{V}$ phase, consisted of obsidian from Lake Van area, but the other later pieces, from Beidha III-II, PPNB date, were from the Çiftlik area of central Anatolia. Most of the evidence for workshops is related to the flint stones, but no obsidian, with the exceptions of Jericho or Tell Mureybet. For instance, Tell Sheikh Hassan yielded only five pieces of obsidian during the PPNA, as also did Jericho or Mureybet for the same period.

\section{The possibility of Late PPNB "World" Systems during the South West Asian Aceramic Neolithic}

The previous model of a PPNB interaction sphere suggest a socio-economic Neolithic core-periphery system, based on the trade of prestige goods, such as obsidian, sea shells, bitumen, and so on (Bar-Yosef and Belfer Cohen, 1989; Bar-Yosef, 2001b; contra, Asouti, 2006: 112). 
The use of the concept of global systems began to be in vogue in the mid-1970s, after the publication of Wallerstein main work (1974, 1980, 1989 and 2011). After this publication, the Global System presumably had been initiated in the sixteenth century, but soon the theory was reinterpreted and expanded to several cores and their peripheries in early dates (Sahlins, 1988; Frank, 1998; Beaujard, 2007, 2010 and 2012). Subsequently, within the literature and archaeological and anthropological research, a new flow of the question about the World System occurred in the mid-1990s with new works (Mederos, 1995). Already Schneider (1977: 25) proposed the existence of other types of ancient World economies and the development of not static core-periphery relations, different and earlier than the one proposed by Wallerstein (1991), for Mesopotamia, Central Asia and Iran (Kohl, 1989), the gulfs of Arabia and Oman (Edens, 1992), the Circum-Pontic region (Sherratt, 2003), the Trans-Eurasian exchange with China (Sherratt, 2006), or Bronze and Iron Age Mediterranean and continental Europe between 2500 and 500 BC (Sherratt, 1993; Kristiansen, 1998a, 1998b and 2007; Kristiansen and Larsson, 2005). From the field of Sociology, there is a global analysis by Frank for the Bronze (1993; Frank and Thompson, 2005; Beaujard, 2011) and the Iron Ages (Frank and Thompson, 2006), five millennia BP onwards, with the decline of old cores and emergency of a new World-System in the old peripheries. Also, Grinin and Korotayev (2013: 17) support a beginning of the Afroeurasian World-System since the transitional period from foraging to food production societies, which took place in the 10th-8th millennia BC.

The Theory of the World System previously has been used for presumed prehistoric empires in the territories of ancient Mesopotamia and adjacent territories by Algaze, with the presence of colonies and trading outposts, for whom the south-controlled expansion integrated and succeeded in "globalizing" the entire Mesopotamian region during the IV millennium B.C. and the Uruk expansion (Algaze, 1989, 1993/2004 and 2001); a model with critics such as Stein who suggests an alternative distance-parity interaction (Stein, 1998 and 1999).

World economies are decentralized political systems of societies interconnected by authentic ties of an economic nature with centers, semi-peripheries and peripheries. Beyond the peripheries, there are external mini-systems, connected with small-scale exchanges, normally luxury goods (Wallerstein, 1974: 301-302). In the case of Aceramic Neolithic, there is irrefutable evidence of long-distance connections and a big amount of travel-time for transport by human muscle power, and the transfer of thousands of obsidian tools and raw material put into circulation, with transfer of surplus between cores and peripheries, just after the apparition of sedentarism but before the development of nomadic pastoralism. Could it mean an economic asymmetry in power relationships between core and peripheries, because the necessary supply for the core of certain raw materials such as obsidian? Could the core areas control the exchange system? If the domestication of wheat might be interrelated with the celebration of feasting through beer making, could be related the management and later domestication of some big animals as young bovines (aurochs, Bos primigenius) or Asiatic wild ass (Equus hemionus) with the long distance transport of raw materials? In this sense, it is interesting to note that after the prevalence of goitred gazelle (Gazella subgutturosa), with 7.949 bones, the main mammalians at Göbleki Tepe (Peeters and Schmidt, 2004: 183 table 1, 208), are the aurochs, with 2.574 bones, and about half of the total meat consumed, and the Asiatic wild ass, with 1.177 bones.

They undoubtedly suggest the interconnection of peoples' societies where agriculture was not fundamental at first for their sedentary process during PPNA (Hodder, 2003). First with the old chains of intermediaries, but later events, from PPNB Middle onwards, with an agrarian economic strategy, came to consider it not only as a strategy of additional survival, obsidian was "good in itself", a private property sign, and a new time with another complex social and ritual world, where goods "had a price".

If we assume several presumed Late PPNB "World" Systems, it has still some archaeological gaps to probe its total expansion (Watkins, 2008: 146). To date, no presence of PPN cultures have been discovered in some portions of the Anatolian Peninsula, especially in the Cilician coastal plains or the coastal Northwestern Turkey, the Mediterranean area around current cities and districts of Antalya and Izmir. Perhaps different coastal lines and geographical formations on such areas, are the explanations (Özdogan, 1999: 208). There were also then some indications of the presence of pre-pottery sites from other regions, increasing gradually, such as Ökuzini in Antalya region, Keçiçayir, Kabakh, Çalca, and Musluçesme in Western Anatolia (Özdogan, 1997 and 2013).

The PPNA shows regional variants accused in the different territories studied here. Only generations before were dispersed clans living in mobile or semi-permanent settlements. The river offered them construction materials and means of communication, independent of the old inland routes. After our judgement, later with the experimentation they would see that with the irrigation of the water of the river they had an extra strategy of survival first and then strong economic goods. Also PPNA societies seemingly develop in progressive way animal domestications as a collateral survival strategy rather than an end in itself.

However the PPNB shows a greater generalization and a site aggregation process, despite certain differences in the regional material culture. For this second period, although of different character according to each region, the domestication was present at global level from Middle PPNB onwards; then there were more societies based on plants and animals, and others rooted on certain animals.

Regarding the architectural changes, our interpretation is that the earliest appearance of monumental buildings at Göbekli suggests that those centers were "keepers of the control" over long distances, from the Upper Euphrates until the Southern Levant. Those people from Jericho or 


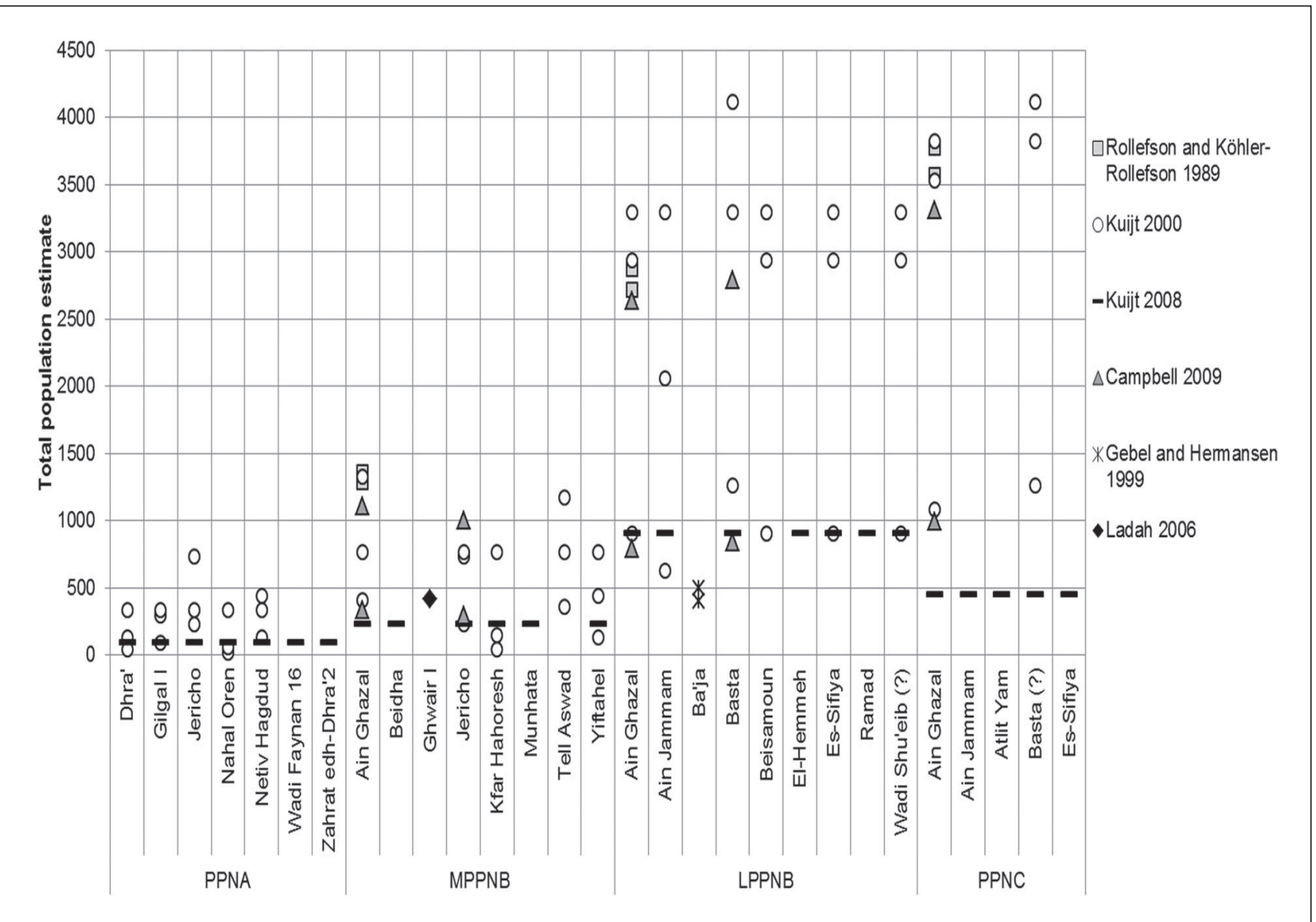

Figure 12. PPNA-PPNB, population estimates in big villages (Birch-Chapman et al., 2017: 3 fig. 1).

close areas must have used the idea in their own benefit, when reached the control on extensive resources and becoming one of the dominant cores in the pressumed Near Eastern Aceramic "World" Systems. Later on, the Euphrates polities changed their nature, and then with pale influxes of the older religion and rituals only present in a few sites such as Nevali Çori or Çayönü. This last one place, was influenced, if no partly occupied, during the Mid-PPNB onwards, by some peoples in contact with the Southern Levantines, as some common traits in the obsidian lithic industry or animal and plant diet strategy suggested.

Most of the big PPN centers seem focused on managing a larger amount of people than smaller places did. While religious PPNA-Early PPNB centers, such as the Göbekli case, were in use at least during a specific period of time each certain months per year, later on the increasing domestication of animals and plants gave an access to a new kind of villages, the typical permanent settled sites of Mid/Late PPNB. The domestication in the PPNB must have been another strategy to keep the control of the people living there or under the influence those new big sites (fig. 12).

During the PPNB they had no longer a few central places for temples or pilgrimage, as Göbekli Tepe in Eastern Turkey (and WF 16? in Jordan), as there was in the PPNA.
In the PPNB period the things appear different, with several major, plausibly central places, attracting people in their regional or at least regional area of influence, and acting as central settlements with a complex organization and diverse functions, including at least one central meeting building where ritual activities were performed.

The population increased such as also did the competition. Several centers grew bigger at the same time, and then the control of the networks and the environment resources became tight. Clashes appeared, as suggests the overall strong evidence for arrowheads in the Middle-Late PPNB, tools so craftly specialized and finely made that surpassed any usual hunting purposes. The environment in several regions became very changing and unstable, and the economic and societal strategies proved unsuccessful, thus provoking either migrations or the collapse of the whole old system.

Since the Mid-PPNB phase, the existing sites yield data about an increase of surplus: storage buildings, large amounts of lithic tools and far distant products (mainly obsidian). The rise in the number of settlements and the reoccupation of a few abandoned sites (such as Abu Hureyra) placed in strategic spots with access to commodities or natural resources, could be a reflection of a phenomenon bigger than just a demographic pressure at the time. The increasing dispersal of sites since Mid- 
Late PPNB could be a result of a "trade commodities" rush. Upper Euphrates villages show more evidence of storage or aggressive artifacts (lithic points, sling balls) than elsewhere. It seems a welfare period, but with ups and downs.

Middle PPNB sites in the Upper Euphrates (Cafer Höyük) or in the Southern Levant (Beidha, Basta) experienced a good reorganization of architecture. After the early experimentation of clay and mudbricks on the Euphrates area, it could be a sign of the later development for cooked pottery in the region. Several attempts of unbacked "pots" are witnessed during the PPNB in several distant sites (cf. Mureybet, Tell Sheikh Hassan, Beidha phase VI, or the stone vessels from the long room phase of Çayönü). It could be the exchange of the ideas among both areas plus the architectural experimentations on clay materials (present in Mureybet III and Munhata IV) and mudbricks, and so bringing together, later on, the apparition of pottery. Sheep dung from on-site defecation by captive animals was used no only for fireplaces, but also as temper in mudbricks, and probably was a stimulus for animal domestication as shows Aşikli Höyük. Time after, following the collapse of this PPN system, another strategy for sedentary settlements, was improved, after a technology: the apparition of the production of clay pottery and so on the birth of standard ceramics. And probably as a main result after the use of mudbrick technology. In such way, the early pottery was far from a commodity on circulation: but a good possibility to count on measures and sizes, and another strategy for certain sites to control through the production of pottery.

\section{ACKnowledgements}

An early version was presented in the XVII Congreso de la Unión Internacional de Ciencias Prehistóricas y Protohistóricas (Burgos, 2014) in the session North-South Connections and Disconnections in the Prehistory and Protohistory of the Levant. The English edition of this paper was cured by Alfred Ahlmann, Alan Cooper and Jasmine Hong.

\section{BiBLIOGRAPHY}

Akkermans, P.A. (1982): "The 1976-1977 Excavations at Tell Bouqras". Annales Archaeologiques Arabes Syriennes, 32: 45-57

Algaze, G. (1989): “The Uruk Expansion: Cross-cultural Exchange in the Early Mesopotamian Civilization". Current Anthropology, 30 (5): 571-608. DOI: https:// doi.org/10.1086/203786

Algaze, G. (2001): “The Prehistory of Imperialism: The Case of Uruk Period Mesopotamia”. In M. Rothman (ed.): Uruk Mesopotamia and its neighbors: Cross-cultural interactions and their consequences in the era of state formation. SAR Press. Santa Fe: 27-84.
Algaze, G. (1993): The Uruk World System: The Dynamics of Expansion of Early Mesopotamian Civilization. University of Chicago. Chicago.

Algaze, G. (1993/2004): El Sistema Mundial Uruk. Bellaterra. Barcelona.

Alley, R.B.; Marotzke, J.; Nordhaus, W.D.; Overpeck, J.T.; Peteet, D.M.; Pielke, R.A.; Pierrehumbert, R.T.; Rhines, P.B.; Stocker, T.F.; Talley, L.D. and Wallace, J.M. (2003): "Abrupt climate change". Science, 299: 2005-2010. DOI: https://doi.org/10.1126/science. 1081056

Alt, K.; Benz, M.; Müller, W.; Berner, M.E.; Schultz, M.; Schmidt-Schultz, T.H.; Knipper, C.; Gebel, H.G.K.; Nissen, H.J. and Vach, W. (2013): "Earliest Evidence for Social Endogamy in the 9,000-Years-Old-Population of Basta, Jordan". PlosOne, 8 (6): 1-9. DOI: https://doi.org/10.1371/journal.pone.0065649

Arimura, M.; Balkan-Atli, N.; Borrell, F.; Cruells, W.; Duru, G.; Erim-Ôzdogan, A.; Ibáñez J.J.; Maede O.; Miyake Y.; Molist M. and Ôzbasaran, M. (2000): “A new Neolithic settlement in the Urfa region Akarçay Tepe, 1999”. Anatolia Antiqua, 7: 227-255. DOI: https://doi.org/10.3406/anata.2000.949

Asouti, E. (2006): "Beyond the Pre-Pottery Neolithic B interaction sphere". Journal of World Prehistory, 20: 87-126. DOI: https://doi.org/10.1007/s10963-0079008-1

Astruc, L.; Abbes, F.; Ibáñez J.J. and González Urquijo, J. (2003): “《Dépôts», «réserves» et «caches» de matériel lithique taillé au Néolithique précéramique au Proche-Orient: quelle gestion de l'outillage?". Paléorient, 29 (1): 59-78. DOI: https://doi.org/10.3406/ paleo.2003.4754

Aurenche, O. (1981): La maison orientale: l'architecture $d u$ Proche-Orient ancien des origines au milieu du 4eme. millenaire. I-III. BAH, 109. Geuthner. Paris.

Aurenche, O. (1993): “L'origine de la brique dans le Proche Orient ancien”. In M. Frangipane, H. Hauptmann, M. Liverani, P. Matthiae and M. Mellink (eds.): Between the rivers and over the Mountains. Archaeologica Anatolica et mesopotamica Alba Palmieri Dedicata. Dipartimento di Scienze Storiche Archeologiche e Antropologiche dell' Antichita, Universita di Roma "La sapienza". Roma: 71-85.

Balkan-Atli, N.; Binder, D. and Cauvin, M.-C. (1999): "Obsidian, sources, workshops, and Trade in Central Anatolia". In M. Ôzdogan and N. Basgelen (eds.): Neolithic in Turkey. The Cradle of Civilization. Arkeoloji ve Sanat Yayinlazi. Istanbul: 133-145.

Banning, E.B. (2011): "So Fair a House: Göbleki Tepe and the Identification of Temples in the Pre-Pottery Neolithic of the Near East". Current Anthropology, 52 (5): 619-660. DOI: https://doi.org/10.1086/661207

Bar-Yosef, O. (1986): "The Walls of Jericho: An Alternative Interpretation”. Current Anthropology, 27 (2): 157-162. DOI: https://doi.org/10.1086/203413

Bar-Yosef, O. (2001a): “The world around Cyprus: From Epi-Paleolithic foragers to the collapse of the PPNB 
civilization". In S. Swiny (ed.): The earliest prehistory of Cyprus. American Schools of Oriental Research. Boston: 129-164.

Bar-Yosef, O. (2001b): "Lithics and the social geographical configurations identifying Neolithic tribes in the Levant". In I. Caneva, C. Lemorini, D. Zampeti and P. Biagi (eds.): Beyond tools. Redefining PPN Lithic assemblages of the Levant. Ex Oriente. Berlin: 437448.

Bar-Yosef, O. (2002): "Natufian: A Complex Society of Foragers". In B. Fitzhugh and J. Habu (eds.): Beyond Foraging and Collecting: Evolutionary Change in Hunter-Gatherer Settlement Systems. Kluwer/Plenum, New York: 91-149. DOI: https://doi.org/10.1007/9781-4615-0543-3 5

Bar-Yosef, O. and Alon, D. (1988): "Nahal Hemar cave. The excavations". Atiqot, 18: 1-30.

Bar-Yosef, O. and Belfer-Cohen, A. (1989a): "The Levantine 'PPNB' interaction sphere". In I. Hershkovitz (ed.): People and culture in change. Proceedings of the second symposium on Upper Paleolithic, Mesolithic and Neolithic populations of Europe and the Mediterranean Basin. British Archaeological Reports, International Series, 508 (1), Archaeopress. Oxford: 59-72.

Bar-Yosef, O. and Belfer-Cohen, A. (1989b): "The Origins of Sedentism and Farming Communinties in the Levant". Journal of World Prehistory, 3: 447-489. DOI: https://doi.org/10.1007/BF00975111

Batist, Z. (2014): Obsidian circulation networks in Southwest Asia and Anatolia (12.000-5700 B.P.): a comparative approach. Thesis. Master of Arts. McMaster University. Hamilton, Canada.

Beaujard, P. (2007): "East Africa, the Comoros Islands and Madagascar before the sixteenth century. On a neglected part of the World-System". Azania, 42: 15-35. DOI: https://doi.org/10.1080/00672700709480448

Beaujard, P. (2010): "From Three Possible Iron-Age World-Systems to a Single Afro-Eurasian World-System". Journal of World History, 21 (1): 1-43. DOI: https://doi.org/10.1353/jwh.0.0097

Beaujard, P. (2011): "Evolutions and temporal delimitations of possible Bronze Age world-systems in western Asia and the Mediterranean". In T.C. Wilkinson, S. Sherratt and J. Bennet (eds.): Interweaving Worlds: Systemic Interactions in Eurasia, $7^{\text {th }}$ to the $1^{\text {st }}$ Millennia $B C$. Oxbow Books. Oxford: 7-26.

Beaujard, P. (2012): Les Mondes de l'océan Indien. 2. L'océan Indien au cour des globalisations de l'Ancien Monde. Armand Colin. Paris.

Belfer-Cohen, A. (1991): "The Natufian in the Levant". Annual Review of Anthropology, 20: 167-186.

Betts, A. (1994): "Qermez Dere: The Chipped Stone Assemblage". H.G. Gebel and S.K. Kozlowski (eds.): Neolithic Chipped Stone Industries of the Fertile Crescent. Ex Oriente. Berlin: 189-204.

Bicakçi, E. (1995): "Çayönü house models and reconstruction attempt for the Cell-plan building". Halet Çambel için Prehistorya Yazıları/Readings in Prehis- tory: Studies Presented to Halet Çambel. Graphis Yayinlari. Istanbul: 27-39.

Birch-Chapman, S.; Jenkins, E.; Coward, F. and Maltby, M. (2017): "Estimating population size, density and dynamics of Pre-Pottery Neolithic villages in the central and southern Levant: an analysis of Beidha, southern Jordan”. Levant, 49 (1): 1-23. DOI: https://doi.org/ 10.1080/00758914.2017.1287813

Bocquentin, F.; Khalaily, H.; Bar-Yosef Mayer, D.E.; Berna, F.; Biton, R.; Boness, D.; Dubreuil, L.; Emery-Barbier, A.; Greenberg, H.; Goren, Y.; Horwitz, L.K.; Le Dosseur, G.; Lernau, O.; Mienis, H.K.; Valentin, B. and Samuelian, N. (2014): "Renewed Excavations at Beisamoun: Investigating the $7^{\text {th }}$ Millennium cal. BC of the Southern Levant". Journal of the Israel Prehistoric Society, 44: 5-100.

Bordaz, J. (1973): "Current Research in the Neolithic of southcentral Turkey: Suberde, Erbaba, and their chronological implications". American Journal of Archaeology, 77: 282-288. DOI: https://doi.org/10.2307/503442

Borrell Tena, F. (2006): La gestión de los recursos minerales silíceos en las primeras comunidades campesinas en el Valle Medio del Éufrates (VIII-VII milenios Cal. B.C.). Implicaciones socioeconómicas: el modo de producción lítico. Tesis Doctoral. Universidad de Barcelona. Barcelona.

Brami, M.N. (2014): The diffusion of Neolithic Practices from Anatolia to Europe. A Contextual Study of Residential and Construction practices. 8500-5500 BC cal. PhD Thesis. University of Liverpool. Liverpool.

Byrd, B.F. (2005): Early Village life at Beidha, Jordan: Neolithic spatial organization and vernacular architecture: the excavations of Mrs. Diana Kirkbride-Helbaek. Oxford University Press. Oxford.

Cauvin, J. (1973): “Decouverte sur l'Euphrate d'un village natufien du IX $\mathrm{X}^{\mathrm{e}}$ millenaire av. J.-C. a Mureybet (Syrie)". Comptes rendues de Academie de Sciences, Serie D, 276 : 1985-1987.

Cauvin, J. (1977): “Les fouilles de Mureybet (1971-1974) et leur signification pour les origines de la sédentarisation au Proche-Orient". Bulletin of the American Schools of Oriental Research, 44: 19-47.

Cauvin, J. (1978): Les premiers villages de Syrie-Palestine du IX $X^{e}$ au VII ${ }^{e}$ millénaire avant Jésus-Christ. Collection de la Maison de l'Orient, 4, Série archéologique, 3. Lyon.

Cauvin, J. (1980): "Le Moyen Euphrate au VII ${ }^{\mathrm{eme}}$ millenaire d'apres Mureybet et Cheikh Hassan". In J.C. Margueron (ed.): Le Moyen Euphrate, zone de contacts et d'echanges (Strasbourg, 1977). E.J. Brill. Leiden: 21-34.

Cauvin, J. (1989): “La Stratigraphie de Cafer Höyük-Est (Turquie) et les origins du PPNB du Taurus". Paléorient, 15 (1): 75-86. DOI: https://doi.org/10.3406/ paleo.1989.4486

Cauvin, J. (1997): Naissance des divinités. Naissance de l'agriculture. La Revolution des symboles au Néolithique. CNRS Editions. Paris. 
Cauvin, J.; Aurenche, O.; Cauvin, M.C. and Balkan-Atli, N. (1999): "The Pre-pottery Site of Cafer Höyük". In M. Ôzdogan and N. Basgelen (eds.): Neolithic in Turkey. The Cradle of Civilization. Arkeoloji ve Sanat Yayinlazi. Istanbul: 87-103.

Cauvin J. and Chataigner, C. (1998): "Distribution de l'obsidienne dans les sites archéologiques du Proche et Moyen Orient". In M.C. Cauvin, A. Gourgaud, B. Gratuze, N. Arnaud, G. Poupeau, J.L. Poidevin and C. Chataigner (eds.): L'Obsidienne au Proche et Moyen Orient. Du Volcan à l'Outil. British Archaeological Reports International Series, 738. Archeopress. Oxford: 325-350.

Chataigner, C.; Poidevin, J.L. and Arnaud, N.O. (1998): "Turkish occurrences of obsidian and use by prehistoric peoples in the Near East from 14,000 to 6,000 BP". Journal of Volcanology and Geothermal Research, 85: 517-537. DOI: https://doi.org/10.1016/S03770273(98)00069-9

Connolly, J. (1999): The Çatal Höyük Flint and Obsidian Industry: Technology and Typology in Context. British Archaeological Reports International Series, 787. Oxford.

Coskunsu, G. (2002): “Mezraa-Teleilat Yontmataş Endüstrisi/Mezraa-Teleilat Chipped Stone Industry". In N. Tuna and J. Velibeyoğlu (eds.): Ilısu ve Karkamış Baraj Gölleri Altında Kalacak Arkeoloji ve Kültür Varlıklarını Kurtarma Projesi 2000 Yılı Çalışmaları / Salvage Project of the Archaeological Heritage of the Ilısu ve Karkamış Dam Reservoirs Activities in 2000. Centre for Research and Assessment of the Historic Environment. Middle East Technical University. Ankara: $143-158$.

Croucher, K. (2012): Death and dying in the Neolithic Near East. Oxford University Press. Oxford. DOI: https://doi. org/10.1093/acprof:osobl/9780199693955.001.0001

de Moulins, D. (1997): Agricultural Changes at Euphrates and Steppe Sites in the Mid-8th to the 6th Millennium B.C. BAR International Series 683. Oxford.

Dietrich, O.; Heun, M.; Notroff, J.; Schmidt, K. and Zarnkow, M. (2012): "The role of cult and feasting in the emergence of Neolithic communities. New evidence from Göbekli Tepe, south-eastern Turkey". Antiquity, 86: 674-695. DOI: https://doi.org/10.1017/ S0003598X00047840

Edens, C. (1992): "Dynamics of Trade in the Ancient Mesopotamian 'World System"'. American Anthropologist, 94 (1): 118-139. DOI: https://doi.org/10.1525/ aa.1992.94.1.02a00070

Esin, U. and Harmankaya, S. (1999): “Aşikli”. In M. Ôzdogan and N. Basgelen (eds.): Neolithic in Turkey. The Cradle of Civilization: Arkeoloji ve Sanat Yayinlazi. Istanbul: 114-132.

Flohr, P.; Finlayson, B.; Najjar, M. and S.I. Mithen (2015): "Building WF16 construction of a Pre Pottery Neolithic A (PPNA) pisé structure in Southern Jordan". Levant 47 (2): 143-163. DOI: https://doi.org/10.1179/007589 1415Z.00000000063
Frank, A.G. (1993): "Bronze Age World System Cycles". Current Anthropology, 34 (4): 383-429. DOI: https:// doi.org/10.1086/204184

Frank, A.G. (1998): ReOrient: Global Economy in the Asian Age. University of California Press. Los Angeles.

Frank, A.G. and Thompson, W.R. (2005): “Afro-Eurasian Bronze Age Economics. Expansion and Contraction Revisited". Journal of World History, 16: 115-172. DOI: https://doi.org/10.1353/jwh.2005.0142

Frank, A.G. and Thompson, W.R. (2006): "Early Iron Age Economics. Expansion and Contraction Revisited". In B.K. Gills and W.R. Thompson (eds.): Globalization and Global History. Routledge. London: 139-162.

Gopher, A. (1989): "Neolihic Arrowheads of the Levant: Results and Implications of a Seriation Analysis". Paléorient, 15 (1): 43-56. DOI: https://doi.org/10.3406/ paleo.1989.4484

Grinin, L.E. and Korotayev, A.V. (2013): "Origins of Globalization". In L.E. Grinin, I.V. Ilvin and A.V. Korotayev (eds.): Globalistics and Globalization Studies. Theories, Research \& Teaching. Uchitel Publishing House. Volgograd: 8-35.

Hauptmann, H. (1993): "Ein Kultgebaude in Nevali Çori”. In M. Frangipane, H. Hauptmann, M. Liverani, P. Matthiae and M. Mellink (eds.): Between the rivers and over the Mountains. Archaeologica Anatolica et mesopotamica Alba Palmieri Dedicata: Dipartimento di Scienze Storiche Archeologiche e Antropologiche dell' Antichita, Universita di Roma "La Sapienza". Roma: 37-70.

Hauptmann, H. (1999): “The Urfa region”. In M. Ôzdogan and N. Basgelen (eds.): Neolithic in Turkey. The Cradle of Civilization. Arkeoloji ve Sanat Yayinlazi. Istanbul: 65-86.

Hauptmann, H. and Schmidt, K. (2007): “Die Skulpturen des Frühneolithikums". Badisches Landesmuseum Karlsruhe, Vor 12000 Jahren in Anatolien. Die ältesten Monumente der Menschheit. Begleitband zur großen Landesausstellung Baden-Württemberg im Badischen Landesmuseum 2007. Theiss. Stuttgart: 67-82.

Hodder, I. (2003): "The Lady and the seed: some thoughts on the role of agriculture in the "Neolithic Revolution"'. From Villages to Town. Studies in Honor of Prof. Ufuk Esin. I. Arkeoloji ve Sanat Publications. Istanbul: 129139, 583-622.

Hole, F. (2000): "Is size important? Function and Hierarchy in Neolithic Settlements". In I. Kuijt (ed.): Life in Neolithic Farming Communities. Social Organization, Identity, and Differentiation. Kuwer Academic/Plenum Publishers. New York: 191-209.

Ibáñez, J.J. (ed.) (2008): Le site néolithique de Tell Mureybet (Syrie du Nord): en hommage à Jacques Cauvin. British Archaeological Reports International Series, 1843. Archaeopress. Oxford.

Ibáñez, J.J.; Ortega, D.; Campos, D.; Khalidi, L. and Méndez, V. (2015): “Testing complex networks of interaction at the onset of the Near Eastern Neolithic using modeling of obsidian exchange". Journal of the Royal Society. Interface, 12 (107): 1-11. DOI: 10.1098/rsif.2015.0210 
Kenyon, K. and Holland, T.A. (eds.) (1981): Excavations at Jericho. III.1-2. The Architecture and Stratigraphy of the Tell. British School of Archaeology at Jerusalem. London.

Khalaily, H.; Milevski, I.; Getzov, N.; Smithline, H.; Barzilai, O.; Shlomi, V.; Amani, A.H.; Zohar, D. and Zidan, O. (2010): "Renewed Excavations at Yiftahel (Khalet Khalladyaiah): A late Prehistoric Site in the lower Galilee". In P. Matthiae, F. Pinnock, L. Nigro, N. Marchetti and L. Romano (eds.): 6th International Congress on the Archaeology of the Ancient Near East (Roma, 2009). Harrasowitz: Wiesbaden: 391-397.

Kohl, P.L. (1989): "The use and abuse of world systems theory: the case of the "pristine" west Asian state". En C.C. Lamberg-Karlovsky (ed.): Archaeological Thought in America. Cambridge University Press. Cambridge, Mass.: 218-240. DOI: https://doi. org/10.1017/CBO9780511558221.015

Kristiansen, K. (1998a): Europe before History. Cambridge University Press. London.

Kristiansen, K. (1998b): "The Emergence of the European World System in the Bronze Age: Divergence, Convergence and Social Evolution during the First and Second Millennia BC in Europe". In K. Kristiansen and M. Rowlands (eds.): Social Transformations in Archaeology: Global and Local Perspectives. Routledge. London: 287-324.

Kristiansen, K. (2007): "Eurasian Transformation: Mobility, Ecological Change, and the Transmission of Social Institutions in the Third Millennium and the Early Second Millennium, B.C.E.". In A. Hornborg and C.L. Crumley (eds.): The World System and the Earth System: Global Socioenvironmental Change and Sustainability Since the Neolithic. Left Coast Books. Walnut Creek, CA: 149-162.

Kristiansen, K. and Larsson, T.B. (2005): The Rise of Bronze Age Society: Travels, Transmissions and Transformations. Cambridge University Press. Cambridge.

Kuijt, I. (2000): "People and Space in Early Agricultural Villages: Exploring Daily Lives, Community Size, and Architecture in the Late Pre-Pottery Neolithic". Journal of Anthropological Archaeology, 19: 75-102. DOI: https://doi.org/10.1006/jaar.1999.0352

Kuijt, I. (2008): "Demography and Storage Systems During the Southern Levantine Neolithic Demographic Transition". In J.-P. Bocquet-Appel and O. Bar Yosef (eds.): The Neolithic Demographic Transition and its Consequences. Springer. New York: 287-313. DOI: https://doi.org/10.1007/978-1-4020-8539-0_11

Maher, L.A.; Banning, E.B. and Chazan, M. (2011): "Oasis or Mirage? Assessing the Role of Abrupt Climate Change in the Prehistory of the Southern Levant". Cambridge Archaeological Journal, 21 (1): 1-30. DOI: https://doi.org/10.1017/S0959774311000011

McGovern, P.E. (2009): Uncorking the past: the quest for wine, beer, and other alcoholic beverages. University of California Press. Berkeley, CA-London.
Mederos Martín, A. (1995): “Retorno al pasado?. Comercio o difusión en los análisis de Antiguos Sistemas Mundiales". Trabajos de Prehistoria, 52 (2): 131-141. DOI: https://doi.org/10.3989/tp.1995.v52.i2.422

Mithen, S.I.; Finlayson, B.; Smith, S.; Jenkins, E.; Najjar, M. and Marievic, D. (2011): "An 11.600 year-old communal structure from the Neolithic of southern Jordan". Antiquity, 85: 350-364. DOI: https://doi.org/10.1017/ S0003598X00067806

Moore, A.M.T.; Hillman, G.C. and Legge, A.J. (2000): Village on the Euphrates, from Foraging to Farming at Abu Hureyra. Oxford University Press. Oxford.

Niessen, H.J.; Muheisen, M.Sh. and H.G. Gebel (1987): "Report on the First Two Seasons of Excavations at Basta (1986-1987)". Annual of the Department of Antiquities of Jordan, 31: 79-119.

Nigro, L. (2017): "Beheaded Ancestors. Of Skulls and Statues in Pre-Pottery Neolithic Jericho". Scienze dell'Antichità, 23 (3): 3-30.

Nishlaki, Y. (2000): Lithic Technology of Neolithic. British Archaeological Reports International Series, 840. Oxford.

Notroff, J.; Dietrich, O. and Schmidt, K. (2016): “Gathering of the Dead? The Early Neolithic Sanctuaries of Gobekli Tepe, Southeastern Turkey". In C. Renfrew, M.J. Boyd and Iain Morley (eds.): Death rituals, social order, and the Archaeology of Immortality in the Ancient World. "Death shall have no dominion". Cambridge University Press. Cambridge: 65-81. DOI: https://doi.org/10.1017/CBO9781316014509.006

Özbasaran, M. (1999): “Musular: A General Assessment on a New Neolithic Site in Central Anatolia". In M. Ôzdogan and N. Basgelen (eds.): Neolithic in Turkey. The Cradle of Civilization. New Discoveries: Arkeoloji ve Sanat Yayinlazi. Istanbul: 147-156.

Özbasaran, M. (2011): "Re-starting at Aşikli". Anatolia Antiqua, 27: 27-37. DOI: https://doi.org/10.3406/anata.2011.1087

Özbasaran, M. (2012): “Aşikli”. In M. Ôzdogan, N. Basgelen and P. Kuniholm (eds.): The Neolithic in Turkey. New Excavations and New Research. 3. Central Anatolia: Archaeology and Arts Publications. Istanbul: 135-158.

Özdogan, M. (1997): "The beginning of the Neolithic economies in southeastern Europe: an Anatolian perspective". Journal of European Archaeology, 5: 1-33. DOI: https://doi.org/10.1179/096576697800660267

Özdogan, M. (1999): "Northwestern Turkey: Neolithic Cultures in Between the Balkans and Anatolia". In M. Ôzdogan and N. Basgelen (eds.): Neolithic in Turkey. The Cradle of Civilization. New Discoveries. Arkeoloji ve Sanat Yayinlazi. Istanbul: 203-224.

Özdogan, M. (2013): "Neolithic Sites in the Marmara Region. Fikirtepe, Pendik, Yarimburgaz, Toptepe, Hoca Çesme, and Asagi Pinar"'. In M. Ôzdogan, N. Basgelen and P. Kuniholm (eds): The Neolithic in Turkey. New Excavations and New Research. 5. Northwest Turkey. Archaeology and Arts Publications. Istanbul: 167-269. 
Özdogan, M. and Özdogan, A. (1998): "Buildings of Cult and the Cult of Buildings". In G. Arsebuk, M. Mellink and W. Schirmer (eds.): Light on Top of the Black Hill: Studies Presented to Halet Cambel. Ege Yayınları. Istanbul: 581-601.

Peters, J. and Schmidt, K. (2004): “Animals in the symbolic world of Pre-Pottery Neolithic Göbleki Tepe, south-eastern Turkey: a preliminary assessment". Anthropozoologica, 39 (1): 179-218.

Pétrequin, P. and Pétrequin, A.M. (1993): Écologie d'un outil: la hache de pierre en Irian Jaya (Indonésie). Monographie du CRA, 12. Centre National de la Recherche Scientifique. Paris.

Renfrew, C. (1977): “Alternative models for exchange and spatial distribution". In T. Earle and J.E. Ericson (eds.): Exchanges systems in prehistory. Academic Press. London: 71-90. DOI: https://doi.org/10.1016/ B978-0-12-227650-7.50010-9

Renfrew, C.; Dixon, J.E. and Cann, J.R. (1968): "Further analysis of Near Eastern obsidians". Proceedings of the Prehistoric Society, 34: 319-331. DOI: https://doi. org/10.1017/S0079497X0001392X

Rollefson, G.O. (1989). “The Late Aceramic Neolithic of the Levant: a synthesis". Paleorient, 15 (1): 168-173. DOI: https://doi.org/10.3406/paleo.1989.5112

Rollefson, G.O. (2000): "Ritual and Social structure at Neolithic 'Ain Ghazal”. In I. Kuijt (ed.): Life in Neolithic Farming Communities: Social Organization, Identity, and Differentiation: Kluwer Academic/Plenum Publishers. New York: 165-190.

Rollefson, G.O. and Kafafi, Z.A. (2013): "The town of 'Ain Ghazal'. In D. Schmandt-Besserat (ed.): 'Ain Ghazal excavation reports 3: symbols at 'Ain Ghazal. Bibliotheca neolithica Asiae meridionalis et occidentalis and Yarmouk University, Monograph of the Faculty of Archaeology and Anthropology. Ex oriente. Berlin: 3-29.

Roodenberg, J. (1989): "Hayaz Hoyuk and the Final PPNB in the Taurus Foothills". Paléorient, 15 (1): 91-101. DOI: https://doi.org/10.3406/paleo.1989.4487

Rosenberg, M. (1992): "Hallan Çemi Tepesi, an early aceramic Neolithic site in Eastern Anatolia: some preliminary observations concerning material culture". Anatolica, 18: 1-18.

Rosenberg, M. (1999): "Hallan Çemi”. In M. Ôzdogan and N. Basgelen (eds.): Neolithic in Turkey. The Cradle of Civilization. New Discoveries: Arkeoloji ve Sanat Yayinlazi. Istanbul: 25-33.

Rubio de Miguel, I. (2004): "Religión y procesos de cambio en el Neolítico preceramico del Próximo Oriente". Isimu, 7: 133-168.

Sahlins, M. (1988): "Cosmologies of the Capitalism: the Trans-Pacific sector of 'The World System"'. Proceedings of the British Academy, 74: 1-51.

Schirmer, W. (1983): "Drei Bauten des Çayönü Tepesi”. In R.M. Boehmer and H. Hauptmann (eds.): Beitrage zur Altertumskunde Kleinasiens. Festschrift fur Kurt Bittel: P. von Zabern. Mainz: 155-166.
Schmidt, K. (2006): Sie bauten die ersten Tempel. Das rätselhafte Heiligtum der Steinzeitjäger. Die archäologische Entdeckung am Göbekli Tepe. Beck. Munchen.

Schmidt, K. (2007): "Göbekli Tepe: santuarios de la Edad de Piedra en la Alta Mesopotamia". Boletín de Arqueología PUCP, 11: 263-288.

Schmidt, K. (2010): “Göbekli Tepe-the Stone Age Sanctuaries. New results of ongoing excavations with a special focus on sculptures and high reliefs". Documenta Praehistorica, 37: 239-256. DOI: https://doi. org/10.4312/dp.37.21

Schmidt, K. (2015): Le premier temple. Gobekli Tepe. CNRS Editions. Paris.

Schneider, J. (1977): “Was There a Pre-capitalist World-System”. Peasant Studies, 6: 20-29.

Sevketoglu, M. (2008): "Early settlements and procurement of raw materials: new evidence based on research at Akanthou-Arkosykos (Tatlisu-Ciftlikdüzü), Northern Cyprus". Tüba-Ar, 11: 63-72. DOI: https://doi. org/10.22520/tubaar.2008.0003

Sherratt, A. (1993): "What would a Bronze-Age World System look like?. Relations between temperate Europe and the Mediterranean in later prehistory". Journal of European Archaeology, 1 (2): 1-57. DOI: https://doi. org/10.1179/096576693800719293

Sherratt, A. (2003): "The Horse and the Wheel: The Dialectics of Change in the Circum-Pontic Region and Adjacent Areas, 4500-1500 BC". In M. Levine, C. Renfrew and K. Boyle (eds.): Prehistoric Steppe Adaptation and the Horse. McDonald Institute Monographs. Oxbow Books. Cambridge: 233-252.

Sherratt, A. (2006): "The Trans-Eurasian Exchange: The Prehistory of Chinese Relations with the West". In V.H. Mair, (ed.): Contact and Exchange in the Ancient World. University of Hawai'i Press. Honolulu, HI: 30-61.

Starkovich, B.M. and Stiner, M.C. (2009): "Hallan Cemi Tepesi: High-ranked Game Exploitation alongside Intensive Seed Processing at the Epipaleolithic-Neolithic Transition in Southeastern Turkey". Anthropozoologica, 44 (1): 41-71. DOI: https://doi.org/10.5252/ az2009n1a2

Stein, G. (1998): "World System Theory and Alternative Modes of Interaction in the Archaeology of Culture Contact". In J.G. Cusick (ed.): Studies in Culture Contact: Interaction, Culture Change, and Archaeology. Southern Illinois University. Carbondale: 220-255.

Stein, G. (1999): Rethinking World-Systems: Diasporas, Colonies, and Interaction in Uruk Mesopotamia. University of Arizona Press. Tucson.

Stiner, M.C.; Buitenhuis, H.; Duru, G.; Kuhn, S.L.; Mentzer, S.M.; Munroe, N.D.; Pöllath, N.; Quade, J.; Tsartsidou, G. and Özbasaran, M. (2014): "A foragerherder trade-off, from broad-spectrum hunting to sheep management at Asıkli Höyük, Turkey". Proceedings of the National Academy of Sciences, 111 (23): 84048409. DOI: https://doi.org/10.1073/pnas.1322723111

Stordeur, D. (1999): “Organisation de l'espace construit et organisation sociale dans le Néolithique 
de Jerf el Ahmar (Syrie, $\mathrm{X}^{\mathrm{e}}-\mathrm{IX}^{\mathrm{e}}$ millénaire av JC)". In F. Braemer, S. Cleuziou and A. Coudart (eds.): Habitat et Société, XIX $X^{e}$ Rencontres Internationales et d'Archéologie et d'Histoire d'Antibes: APDCA. Antibes: 131-149.

Stordeur, D. (2000): El Kowm 2: Une ille dans le desert. CNRS Éditions. Paris.

Stordeur, D.; Brenet, M.; Der Aprahamian, G.; Roux, J.C. (2000): "Les bâtiments communautaires de Jerf el Ahmar et Mureybet Horizon PPNA (Syrie)". Paléorient, 26 (1): 29-44. DOI: https://doi.org/10.3406/ paleo. 2000.4696

Verhoeven, M. (2002): "Transformations of Society: The Changing Role of Ritual and Symbolism in the PPNB and the PN in the Levant, Syria and South-East Anatolia". Paléorient, 28 (1): 5-13. DOI: https://doi. org/10.3406/paleo.2002.4735

Wallerstein, I. (1974): The Modern World-System: Capitalist Agriculture and the Origins of the European World-Economy in the Sixteenth Century. Academic Press. New York, NY.
Wallerstein, I. (1980): The Modern World-System II: Mercantilism and the Consolidation of the European World-Economy, 1600-1750. Academic Press. New York, NY.

Wallerstein, I. (1989): The Modern World-System III: The Second Era of Great Expansion of the Capitalist World-Economy, 1730-1840s. Academic Press. San Diego, CA.

Wallerstein, I. (1991): "World system versus world-systems: A critique". Critique of Anthropology, 11 (2): 189-194. DOI: https://doi.org/10.1177/0308275X9101100207

Wallerstein, I. (2011): The Modern World-System IV: Centrist Liberalism Triumphant, 1789-1914. University of California Press. Berkeley, CA.

Watkins, T. (1990): "The origins of house and home?". World Archaeology, 21: 336-347. DOI: https://doi.org /10.1080/00438243.1990.9980112

Watkins, T. (2008): "Supra-Regional Networks in the Neolithic of Southwest Asia". Journal of World Prehistory, 21:139-171. DOI: https://doi.org/10.1007/ s10963-008-9013-z 